\title{
Articles
}

\section{Poisoning the Well: Law \& Economics and Racial Inequality}

\author{
ROBERT E. SUGGS*
}

\section{INTRODUCTION}

The standard Law and Economics analysis of racial discrimination has stunted African-American thinking about race.' This consequence flows not from the cogency of its analysis, ${ }^{2}$ but rather from the conclusion reached by early Law and Economics advocates, when desegregation had just begun, that antidiscrimination laws were wasteful and unnecessary. This hasty, surprising, and flawed conclusion discredited economic analysis as a means to enrich our understanding of racial phenomena, especially among African-American political and intellectual leaders. These leaders now largely ignore economic analysis in favor of cultural critiques of race's role in American society. Insightful and perceptive as such critiques might be, however, they provide no substitute for a careful analysis of race in market transactions. ${ }^{3}$ Law and Economics had this

* Professor of Law, University of Maryland School of Law. For their suggestions and comments I thank my colleagues, Taunya Banks, Daniel Gilman, and William Reynolds, as well as Robin Malloy and panelists at the 8th Annual Conference for the Study of Law, Culture, and the Humanities, participants in the 2005 Annual Meeting of the Midwestern People of Color Legal Scholarship Conference, and the faculty of the Wake Forest University School of Law. For their able research assistance I thank Robert Burriesci, Ryan Easley, Mary Ellen Himes, Brian Marron, Janet Sinder, and Michelle Wilson, and I express my gratitude to the reference librarians who assisted me, Sara Kelley, Pamela Bluh, and Maxine Grosshans. My gratitude extends to other readers as well, including Lisa Dornell and Alice Suggs. All of the Article's shortcomings are my own.

I. Others have been similarly affected. In assessing the impact of Gary Becker's The Economics of Discrimination (2d ed. I97I), a leading commentator concluded that the book "succeeded in inhibiting the minds of economists in a way that seemed to stifle further theoretical developments in much the way that weeds stifle the growth of more desirable vegetation." I The New Palgrave Dictionary of Economics and the Law 616 (Peter Newman ed., 1998) [hereinafter Palgrave].

2. Errors in its analysis are the subject of Part $I$, infra.

3. In Devon Carbado \& G. Mitu Gulati, The Law and Economics of Critical Race Theory: Crossroads, Directions, and a New Critical Race Theory, II2 YALE L.J. 1757, 1778 (2003) (book review), the authors make a similar observation: "To the extent that identity privileges are a function 
pernicious impact despite offering a fundamentally flawed analysis. Many have critiqued its assumptions (far better than I am able), but the analysis erred, even accepting contestable assumptions, because it ignored the possibility that victims of discrimination could have psychic losses.

As a discipline, economics has become strongly identified with conservative justifications for the validity and inevitability of persistent inequality. Economists restrict their analysis of racial discrimination in market transactions to labor markets, a well developed field. They devote virtually no effort to the effects of racial discrimination in commercial transactions, the choices by business firms of their customers and suppliers. The result has been to impoverish our understanding of race and commercial transactions and leave a gaping hole in the policy agenda aiming to create greater equality of opportunity.

Given the wealth and power of the business community, racial discrimination in this sector ought to be of paramount concern. Private business firms account for four fifths of all economic activity. ${ }^{4}$ Exclusion or disadvantage in such a significant economic sphere must create major distortions in political participation, popular culture, self-employment, personal income, and especially aggregate wealth.

Over the past several decades, federal, state, and local governments have enacted an array of laws designed to address racial inequalities in education, housing, and employment. Yet the racial landscape has changed little in half a century. Nationwide, levels of both school and residential segregation show little sign of significant change. ${ }^{5}$ Despite a legal revolution in civil rights, income inequalities have persisted within the same narrow range for many decades. ${ }^{6}$ Perhaps these disparities have

of, and help to entrench, discrimination, the question is how to dismantle them. None of the essays in A New Critical Race Theory articulates an answer."

Engineering economic policy is fraught with examples of unintended consequences, but compared to cultural policy interventions which involve far more complicated and dimly perceived phenomena, economics is comparatively precise. One major scholar, Richard Delgado, has criticized much critical scholarship for being focused "almost exclusively on discourse at the expense of power, history, and similar material determinants of minority-group fortunes." Richard Delgado, Crossroads and Blind Alleys: A Critical Examination of Recent Writings About Race, 82 TEX. L. REV. I21, 122 (2003); see also Kevin R. Johnson, Roll Over Beethoven: "A Critical Examination of Recent Writing About Race," 82 Tex. L. Rev. 717 (2004) (in a rejoinder).

4. See Bureau of Economic Analysis, U.S. Dep't of Commerce, Table I.I.5. Gross Domestic Product, available at http://www.bea.gov/bea/dn/nipaweb/TableView.asp?SelectedTable $=5 \&$ First Year $=2004 \&$ Last Year $=2005 \&$ Freq=Qtr (last revised Oct. 28, 2005). Government activity accounts for roughly twenty percent of GDP. Id.

5. See generally Douglas S. Massey \& Nancy A. Denton, American Apartheid: Segregation AND THE MAKING OF THE Underclass 86 (I993) (discussing continuing residential segregation); Gary Orfield, Turning Back to Segregation, in Dismantling Desegregation: The Quiet Reversal of Brown v. BOARD OF EDUCATION I (Gary Orfield \& Susan E. Eaton eds., 1996).

6. See infra note 90 . 
been intractable because racial disparities in levels of business revenues dwarf those in levels of income by orders of magnitude.

Furthermore, no federal, state, or local legislation has ever prohibited racial discrimination in commercial transactions between business firms. Since race has proved an enduring barrier in housing, education, employment, and other areas-despite laws that actually prohibit discrimination-its influence on business activity likely continues unabated. Legal toleration of business discrimination makes the paucity of our economic understanding of the effects of race on commercial transactions especially pernicious. If reducing racial inequality requires a substantially larger African-American business presence in the economy, and discrimination inhibits the growth of that presence, then what policies might reduce discrimination? To eliminate racial discrimination from commercial transactions, we cannot simply prohibit it; more is required.

The requirements of a market economy make prohibitions against racial discrimination in private commercial transactions impractical, ${ }^{7}$ because effective enforcement would necessitate abandoning the market economy. Because prohibition is unavailable, market incentives remain the only force available to erode racial barriers to commercial transactions, and these must not offend equal protection doctrine. Yet devising market interventions presupposes a sophisticated understanding of the way race affects market transactions, and we currently lack the necessary comprehension.

Market interventions that encourage African-American business development must consider not only the direct effects of market incentives, but also the possible responses of a dynamic marketplace as all economic actors, not just the intended beneficiaries, seek to exploit the opportunities these incentives provide. The evolving nature of the way race operates in our society, combined with the continual addition of new ethnic groups to the mix, further compounds the analytical difficulty. Without a sophisticated understanding of the way race and markets interact, mobilizing political constituencies and convincing them to commit to long term interventions which promise only slow cumulative progress becomes extremely difficult. These constituencies have, and should have, reasonable doubts that the policies will work as intended. Further, the inherent difficulty is exacerbated by the fact that the

7. Without imposing the procedures generally found in public procurement, i.e., public notice of bid opportunities, public award of bids on a sealed basis, and an obligation by customers to accept the low bid, victims of discrimination have no way to learn the information needed to submit a meaningful and timely bid, learn why their bids were not accepted, or even whether their bid was more favorable. Even with these procedures in public procurement, no plaintiff has ever succeeded with a claim of business discrimination. For a more complete discussion, see Robert E. Suggs, Racial Discrimination in Business Transactions, 42 Hastings L.J. I 257, I284-87 (1991). 
audience whose political support is sought distrusts the discipline used to identify desirable policies.

Law and Economics is not solely responsible for this state of affairs. Its rash and mistaken analysis of racial discrimination discredited economic analysis within the civil rights community, but other cultural factors peculiar to African-American history were at work as well. While these factors will be discussed in general terms, the principal goal of this Article is to contribute to the redemption of economics' reputation as a source of insights into the way race operates in our society.

The schools of economics whose reputations provoke this concern do not include the neoclassical school of microeconomics, which provides the foundation for Law and Economics. Rather, the appropriate concern is for the many other schools whose approaches might enrich our understanding by revealing the scale and direction of economic incentives for various behaviors. To refurbish the legitimacy of these other schools, it helps first to show that even Law and Economics does not produce foolish results. Thus, this analysis starts with showing how Law and Economics erred, even by its own lights, as a first step towards my goal. Having shown this error, the analysis will then correct it. No claim will be made that Law and Economics, as corrected, reaches wise answers, or even any particular answer. Instead, the only claim made is that its corrected analysis does not contradict common experience or preach lunacy.

Part I of this paper presents the mistake that Law and Economics made: a gross oversight in its analysis of a factor that while in plain view was invisible. Remarkably, even those who argued strenuously against the Law and Economics approach experienced the same blind spot. This Part also attempts to account for why the oversight occurred. It finds a partial explanation in the evolution of the analysis, during which insufficient attention was given to implicit limiting assumptions contained within Gary Becker's original individual firm level analysis. The persistence of the error over the intervening decades invites speculation about the cognitive and psychological factors at work, but I have resisted that temptation and leave investigation of this phenomenon to other disciplines. This Part also corrects the Law and Economics analysis and extends the analysis, as corrected, to indeterminate results.

Part II identifies the cultural and historical factors that contributed to the civil rights community's neglect of the effects of race on commercial transactions and business discrimination in general. It attempts to explain why the Law and Economics analysis had such a major discrediting effect on an entire discipline.

Part III discusses racial disparities in income, wealth, and business activity. It argues that significant business ownership creates private 
power, and that it is the absence of such power, unconstrained by political accountability and public scrutiny and legal doctrines restricting purposes and beneficiaries, that helps explain persistent inequality.

Part IV applies economic analysis to illustrative racial phenomena, residential segregation and credit redlining, and poses the new questions that such an analysis provokes. To the critique of Becker's work in Part I, it adds a critique of statistical discrimination and suggests that approaches based upon the economics of information collection and verification might prove fruitful.

This article concludes with a plea for greater efforts to understand the way racial phenomena operate in commercial markets. If greater African-American business activity reduces inequality, we all stand to benefit. Not only will our economy make better use of its human resources, but our society will experience greater social cohesion because business is not just a way to make money. It is also a major cultural activity, and has been since the earliest urban civilizations. By more closely aligning economic and commercial interests across racial boundaries, we will also reduce the social and political salience of race.

\section{The Invisible Man in Law and Economics}

Numerous scholars from multiple disciplines have challenged Law and Economics on a variety of grounds. Those challenges have succeeded. The assumptions critical to the neoclassical microeconomic model upon which Law and Economics is based have been thoroughly critiqued. Empiricists have gradually accumulated voluminous evidence of systematic deviations from the rational choice model. Its "neutral" goal of economic efficiency has been shown to be value-laden and dependent on initial distributions. Moreover, its methodological individualism is in fundamental tension with the concept of race, intrinsically a group concept. I will not review all of this work. Instead, I will accept the assumptions of Law and Economics as true and show that it still made a fundamental error, and a fundamentally simple one. It made an error of perception.

Microeconomic quantitative analysis of racial discrimination began with the publication of The Economics of Discrimination in 1957, the doctoral dissertation of future Nobel laureate Gary Becker. ${ }^{8}$ In Becker's words, "the major contribution" of the book is to develop a theory of non-pecuniary motivation and to apply it quantitatively to discrimination in the market place."

8. BeCKer, supra note I. He won the Nobel Prize in Economic Sciences in 1992. BanNock ET AL., Dictionary of ECONOMics 31 (I998).

9. Its lasting contribution may be methodological.

IO. BECKER, supra note I, at I I. 
Becker quantified and monetized the level of discrimination by attributing it to a taste by whites for nonassociation with blacks. An individual with such a taste acts " $a$ s if he were willing to pay something, either directly or in the form of a reduced income, to be associated with some persons instead of others." Quantification resulted when he posited that white workers and employers would willingly forego certain amounts of wages and profits to satisfy their preferences for nonassociation. ${ }^{12}$ The amount of wages or profits foregone became the quantity, or dollar amount, of discrimination. Conversely, when whites could not satisfy their preference for nonassociation, then they had incurred a psychic cost of an equal amount.

By quantifying discrimination in this manner, Becker could mathematically model racial discrimination, and mathematical models provide predictions which can be confirmed or refuted by empirical evidence. This ability to create mathematical models, which in turn generate empirical predictions, gives neoclassical microeconomic theory a powerful allure. This allure blinded many legal scholars, who seized upon this new tool and applied it to long term historical and broad social and cultural phenomena while ignoring its limiting assumptions.

Becker reasoned ${ }^{13}$ that if an employer discriminated against black workers, there would be two effects. First, demand for black workers with the relevant skills would be depressed, and with no reduction in supply, such workers would, at the margin, be willing to work for lower wages $^{14}$ (an employer practice currently barred by Title VII ${ }^{15}$ ). They

II. Id. at I4.

12. Considerable empirical data have accumulated over the past dozen years in the field of affective forecasting from experiments by psychologists and economists that strongly suggest that individuals are not very good at predicting the intensity or duration of happiness or unhappiness. The evidence suggests that we systematically overestimate both the happiness of positive events and the unhappiness of negative events. See Jon Gertner, The Futile Pursuit of Happiness, N.Y. Times, Sept. 7 , 2003 , $\$$ 6, at 44 (discussing the work of Daniel Gilbert, Daniel Kahneman, George Lowenstein, and Timothy Wilson). Their empirical work suggests that (consistent with the historical record) the experience of desegregation would not be nearly as painful and traumatic as whites anticipated. The further implication of their work is that preferences do not remain stable over time, but can vary in intensity, contradicting one of the most significant assumptions of the standard neoclassical model. See also Jeremy Blumenthal, Law and the Emotions: The Problems of Affective Forecasting, 80 IND. L.J. I55 (2005).

13. Becker modeled discrimination by employers, employees, and consumers, but most of the law and economics incorporation and development of his theory has focused on employer discrimination (probably because Title VII only prohibits discrimination by employers and does not reach discrimination by employees and consumers, except by prohibiting employers from allowing or permitting such discrimination).

I4. See BECKER, supra note I, at I9-2I.

15. Civil Rights Act of $1964 \S 703$ (a)(I), $4^{2}$ U.S.C. $\S 2000 e-2(a)(1)(2000)$ ("It shall be an unlawful employment practice for an employer-[I] (I) ... to discriminate against any individual with respect to his compensation, terms, conditions, or privileges of employment, because of such individual's race, color, religion, sex, or national origin ...."). 
would then be employed at lower wages than white co-workers by employers who chose not to discriminate in hiring. Second, since equally skilled black workers (assumed to be as productive as white workers), would work at lower wages, non-discriminating employers would earn more profits than employers that discriminated and hired only more costly white workers. ${ }^{16}$ Over time,${ }^{17}$ non-discriminating employers would either drive discriminating employers out of business or acquire their firms, since the same firm would be worth more to the nondiscriminating employer because it would generate more profits for a non-discriminating employer than for a discriminating one. ${ }^{18}$

Accepting this logic, Law and Economics adherents then generalized this conclusion to the entire economy and concluded that because market forces will make racial discrimination unprofitable, laws prohibiting employment discrimination by employers become largely unnecessary. ("Becker himself was more cautious, and claimed only that "under certain conditions' would competitive markets eliminate discriminatory employers.") ${ }^{19}$ Thus, only when governments mandate segregation or themselves practice discrimination are legal mandates against discrimination needed. In the latter circumstance market competition cannot penalize discriminating governments because they, like monopolies, face no competition.

Furthermore, (the Law and Economics argument continued), because antidiscrimination laws impose regulatory and compliance costs, but do not contribute to production or efficiency, ${ }^{20}$ employment discrimination laws waste resources. ${ }^{21}$ To Law and Economics adherents

I6. See BECKER, supra note I, at 2 I, 43-45.

17. The amount of time is not specified. The longer the time, the greater the likelihood that intervening factors might disrupt the prediction. Even Becker implies a lengthy time period. He noted the remarkable stability over decades of the relative occupational positions of "Negroes," both North and South, from 1910 to I950. BECKER, supra note I, at I 56.

18. See id. at 43-45; Richard A. Posner, Economic Analysis of Law § 21.1 (1972). But see Deborah M. Figart, In Pursuit of Racial Equality: The Political Economy of Rhonda M. Williams, 28 Rev. B LACK POL. ECON. I3, I5-16 (2001) (discussing Rhonda Williams, who argued with others that employers could maintain dual or segmented labor markets and that discriminating employers could take advantage of depressed wages for black workers and make extra profits).

19. Stewart J. Schwab, Employment Discrimination, in 3 ENcyclopedia of Law and Economics 572, 576 (Boudewijn Bouckaert \& Gerrit De Geest eds., 2000) (citing BEcKer, supra note I, at 45). The full text of Becker's statement was "Nevertheless, under certain conditions the equilibrium MDC [Market Discrimination Coefficient] would equal zero, and consequently, all surviving employers would be maximizing money income." BECKER, supra note $\mathrm{I}$, at 45 .

20. To the extent that antidiscrimination laws ensure that more productive workers are not discriminated against, these laws do contribute to efficiency. In the firm-specific sense, workers discriminated against would work in their second or third best roles. If workers face discrimination and cannot work in their highest value added positions, their productivity is less than their potential.

21. "The aggregate costs of these [Title VII] cases, and of the many more matters that are settled without litigation, must be considerable... Title VII may generate substantial costs over and above the costs of administering the statute... Title VII may not be effective, in which event its 
these costs make antidiscrimination laws both inefficient and unwarranted. These costs, they have argued, exceed any possible benefit, because market competition alone would drive discriminating employers from the marketplace without requiring any antidiscrimination legislation. The costs of enforcement thus become unnecessary and constitute waste. Further waste occurs when antidiscrimination laws distort economic decisions by causing employers to adopt inefficient practices to avoid the costly litigation that might result from close cases, mistaken plaintiffs, and strike suits. ${ }^{22}$ Ironically (to their minds), laws mandating equal pay for equal work, ${ }^{23}$ part of the civil rights infrastructure, bar non-discriminating employers from reaping the enhanced profits that would flow from their willingness to hire black workers at wages depressed by the discrimination of other employers. Civil rights laws prevent market competition from penalizing employers that discriminate, or so the argument goes. Without such laws, black workers, by accepting less pay, make non-discriminating employers more profitable (essentially bribing them to forgo their preference for nonassociation). When more profitable non-discriminating firms have acquired or driven out of business all discriminating firms, the supply of black workers would no longer exceed the demand and black and white wages would equalize (and also eliminate the, wage disparity which motivated the non-discriminating employers to forego their preference for nonassociation in the first place). ${ }^{24}$

The prominence of some of the initial proponents ${ }^{25}$ of Law and Economics within legal academia, combined with their rejection of civil rights reforms on "respectable" grounds, i.e. those not explicitly segregationist, gave immediate appeal in some circles to the general policy conclusion to which they prematurely leaped-that antidiscrimination laws were both unnecessary and a wasteful burden on

administrative costs are a dead weight loss." Richard A. Posner, The Efficiency and the Efficacy of Title VII, 136 U. PA. L. Rev. 513, 514 (1987).

22. See Johnson v. Transp. Agency, 480 U.S. 616, 664-77 (1987) (Scalia, J., dissenting).

23. See, e.g., Civil Rights Act of $1964 \S 703(\mathrm{a})(\mathrm{I}), 42$ U.S.C. $\$ 2000 e$ et seq. (2000). Prior to enactment of this law, employers could, and usually did, pay minorities and women a lesser wage for performing the same jobs as white male workers.

24. Having black workers bribe white workers to forego their preference for nonassociation as employees is more difficult. To allow employers to pay a premium to white workers that are unable to satisfy their preference for nonassociation, black wages must be below those of white workers. Put another way, the employer would have to pay white workers in an integrated work force more than he would if the work force were all white. As a consequence in response to the desire for nonassociation of white employees, an income maximizing white employer would hire an all black or all white work force, but not a mixed group. BECKER, supra note I, at 56 .

25. Professors Richard Posner (then a faculty member at the University of Chicago Law School and now a judge on the U.S. Seventh Circuit Court of Appeals) and Richard Epstein (a Chicago colleague). 
the economy. ${ }^{26}$ These proponents reached this conclusion less than a decade after passage of the Civil Rights Act of $1964,{ }^{27}$ which among other things, desegregated public accommodations. This legislation, America's first modern wholesale attempt at desegregation, encountered bitter resistance both before and after enactment. ${ }^{28}$ Their recommendation proposed exchanging the first concrete and widespread civil rights gains since Reconstruction for the predictions of an economic theory whose assumptions flatly contradicted common experience. To advocates of civil rights, this recommendation hardly seemed credible in the context of an affirmative action debate which included many vehement critics of the initial efforts to dismantle state-mandated segregation. This recommendation ignored both American history and the law-like role played by this era's racial norms. ${ }^{29}$ Employment discrimination and even government discrimination, particularly in the industrial North, were enforced through custom and tradition, i.e. social norms, which had the effect of eliminating market competition for the services of black employees. ${ }^{30}$ Even assuming market competition existed and operated in close approximation to the Law and Economics model, this recommendation came devoid of any timetable for predicting when discriminatory firms might be eliminated from the market place. The

26. "To begin with, not all discrimination is inefficient ...; therefore efforts to prevent it impose a social cost over and above the cost of the efforts themselves." Richard A. Posner, Economic ANALYSIS OF LAW 337 (4th ed. 1992). "[T]he added costs, both direct and indirect, that antidiscrimination laws impose on employers will be passed on in part to consumers, in the form of higher prices." Id. at 337-38. "[T]his consensus [favoring enforcement of the antidiscrimination principle] focuses too heavily on historical injustices... and too little on the economic and social consequences that are generated by the antidiscrimination laws." RICHARD A. EPSTEIN, ForbidDEN Grounds: The Case Against Employment Discrimination Laws 2 (1992) [hereinafter Epstein, Forbidden Grounds]. In fairness, Posner's and Epstein's use of economic analysis extended far beyond issues of race relations, which was treated as a minor topic. Much of their use has been a valuable tool to legal analysis, but it also suffers from the same general weakness identified here; a failure to examine fundamental assumptions in the light of the policy conclusions being recommended.

27. Civil Rights Act of I964, Pub. L. No. 88-352, 78 Stat. 24I; Posner, supra note I8, at 294-306. Posner's Economic Analysis of Law was first published in 1972. Its sixth edition appeared in 2003.

28. Senator Barry Goldwater, the 1964 Republican presidential nominee, "ran as an opponent of mandatory school desegregation and of the landmark Civil Rights Act [of 1964] which Congress had just passed. George H.W. Bush, campaigning for the Senate that year, came out against the Civil Rights Act. Ronald Reagan, then a popular conservative speaker preparing to run for governor of California, strongly opposed it." Nicholas Lehman, The Long March, New YoRkER, Feb. 10, 2003, at 86.

29. See, e.g., Lawrence Lessig, The Regulation of Social Meaning, 62 U. CHI. L. Rev. 943 (1995); Cass R. Sunstein, Social Norms and Social Roles, 96 Colum. L. Rev. 903 (1996) (discussing the power of social norms to regulate behavior and the use of the law in "norm management"). "Social norms are also part and parcel of systems of race and sex equality. If norms changed, existing inequalities would be greatly reduced." Id. at go8; see also Robert C. Ellickson, Order Without LaW: How Neighrors Settle Disputes (1991); Eric A. Posner, Law and Social Norms (2000); Robert Cooter, Normative Failure Theory of Law, 82 CoRnell L. Rev. 947 (1997); Richard H. McAdams, The Origin, Development, and Regulation of Norms, 96 MicH. L. REv. 338 (1997).

30. Law and Economics assumes perfect competition. 
prominence given to the Law and Economics analysis and the resulting policy recommendation, in the context of the political struggle of the times, had an unfortunate result. Before economic approaches to an understanding of racial discrimination could be properly seized upon and developed by the civil rights community, they were thoroughly discredited. ${ }^{31}$

In the view of critics, the initial neoclassical microeconomics approach to the phenomenon of racial discrimination failed miserably. Kenneth Arrow, a prominent economist and Nobel laureate (1972) (2) $^{32}$ criticized Becker's analysis for "predict[ing] the absence of the phenomenon it was designed to explain." ${ }^{33}$ It has been criticized for its "deep flaws, some emanating from its deficiencies in economic modeling, and some from the defects in its premises." ${ }^{34}$ Becker's analysis was ahistorical. ${ }^{35}$ In purporting to model racial discrimination, it assumed facts completely opposite to the common everyday "facts of life" of American society, especially in the South. ${ }^{36}$ Nevertheless, Becker's

31. I refer here to the tools of economic analysis, not necessarily those specific to neoclassical microeconomics, which form the foundation for the school of Law and Economics. As I make clear later, Law and Economics' failure to recognize the limitations imposed by its own assumptions has led it to erroneous conclusions.

32. BANNocK, supra note 8 , at 9 .

33. Kenneth Arrow, Some Mathematical Models of Race Discrimination in the Labor Market, in Racial Discrimination in Economic Life I87-203, I92 (Anthony Pascal ed., I972). This pithy critique is also cited in PALgrave, supra note I, at 616. Even Professor Kenneth Arrow, who disagreed with Becker, failed to consider the psychic costs to discrimination's victims and how victims might react to these costs. This failure occurred despite Arrow's explicit articulation of some of the assumptions underlying neoclassical microeconomics, his recognition of the complicating role of racial perceptions, and his explicit incorporation in his analysis of discrimination (in another article) that "history matters." Kenneth J. Arrow, The Theory of Discrimination, in Discrimination IN Labor Markets 3, 22 (Orley Ashenfelter \& Albert Rees eds., I973). Arrow's analysis concluded that discrimination would survive. "In the end, we remain with wage differences coupled with tendencies to segregation." Id. at 23. Recognition of the psychic costs incurred by black victims of discrimination would have strengthened his analysis and buttressed his conclusions.

34. Palgrave, supra note $\mathrm{I}$, at 615-16.

35. See Ron Harris, The Use of History in Law and Economics, 4 THeoretical Inquiries L. 659 , 66I (2003), for an attempt at an explanation for the ahistorical nature of law and economics based upon an analysis of "its intellectual origins, its methodological paradigm, and the nature of its interaction with other sub-fields of law and of economics."

36. I refer to his conceptualization of racial discrimination as a preference for nonassociation. Since black domestic workers cleaned homes and raised generations of white children in the intimate setting of the home, the preference could not be for nonassociation. Richard H. McAdams, Cooperation and Conflict: The Economics of Group Status Production and Race Discrimination, 108 HARv. L. Rev. 1003, 1036-38 (1995) [hereinafter McAdams, Cooperation and Conflict]. McAdams has rightly pointed out that the preference was for nonassociation as equals:

The key to understanding this behavior is to perceive its subordinating quality. Status comes about by disparaging others, by asserting and reinforcing a claim to superior social rank. Under this view, the associational preference model is partly, but only partly, correct. One obvious way to express disrespect toward others is to refuse to associate with them. But non-association is over- and under inclusive because one can subordinate those with whom one associates and because, when non-association is used, it does not exhaust the means of subordination. 
methodological insight proved seminal. However, while his work represented an important innovation in the application of economic analysis to complex social phenomena such as racial discrimination, its substantive conclusions are unlikely to be its lasting contribution.

The debate between Law and Economics' proponents and their adversaries in the civil rights community centered on whether the actual market would operate as Law and Economics predicted, or whether in practice it would diverge from the model and allow racial discrimination to continue.$^{37}$ Some argued, without any empirical data, that there was no proof that Title VII had improved net black welfare, and that its unintended consequences had offset its benefits. ${ }^{38}$ Yet the most serious and overlooked failing in the Law and Economics movement's effort to apply economic analysis to racial discrimination is its inability and failure

Id. at I044. So long as racial subordination was clear, intimacy did not challenge the reigning white ethos of white supremacy. The problem with McAdams' focus on status production as the revisionary factor that vastly improves Becker's analysis is that racial status is a group phenomenon and neoclassical microeconomics postulates only atomized rational individuals (McAdams argues that individuals will sacrifice their own pecuniary interests to raise the status of their group). The irony is that Beckers assumption is marginally more defensible in 2000 than when published in 1957.

37. While the legal literature is voluminous, labor economists have produced considerably more over a much longer period of time. See, e.g., Derrick A. Bell, Faces at the Bottom of the Well: The Permanence of Racism (1992); Epstein, Forbidden grounds, supra note 26; Walter K. Olson, The Excuse Factory: How Employment Law is Paralyzing the American Workplace (1997); Michael Reich, Racial Inequality: A Political-Economic Analysis (1982); Lea Brilmayer, Lonely Libertarian: One Man's View of Antidiscrimination Law, 3I SAN Diego L. Rev. I05 (1994); Major G. Coleman, Contesting the Magic of the Market-place: Black Employment and Business Concentration in the Urban Context, 39 Urb. Stud. 1793 (Sept. 2002); Drew S. Days, III, Reality, 3i San Diego L. Rev. I69 (1994) (critiquing EPSTEIN, Forbidden Grounds, supra note 26).

As quickly as the twinkling of an eye, Professor Epstein acknowledges dutifully America's history of discrimination against African Americans and passes on. This strategy is central to the overall scheme of his impressive assault upon Title VII. For it is designed to persuade the reader that the history of discrimination has no significant impact upon the current socio-economic status of blacks and their chances for improving that condition, and that racial discrimination is largely a relic of the past. With this obstacle out of the way, the force of his overall argument, if not much of his rhetoric, about the blight of government regulation of discrimination in the workplace seems almost irresistible.

Id. at 169; Richard Delgado, Rodrigo's Second Chronicle: The Economics and Politics of Race, 9I Mich. L. Rev. 1 I83 (1993) (reviewing Epstein, Forbidden Grounds, supra note 26); John J. Donohue, III, Further Thoughts on Employment Discrimination Legislation: A Reply to Judge Posner, 136 U. PA. L. Rev. 523 (1987) [hereinafter Donohue, Further Thoughts]; Robert Cooter, Market Affirmative Action, 3i San Diego L. Rev.i33 (I994); Economics and Discrimination (William Darity, Jr. ed., 1995) (a two volume collection of reprinted articles on this general topic); Richard A. Epstein, The Status-Production Sideshow: Why the Antidiscrimination Laws Are Still a Mistake, I08 Harv. L. Rev. I085 (1995) [hereinafter Epstein, Status-Production]; Richard H. McAdams, Relative Preferences, I02 Yale L.J. I (1992) [hereinafter McAdams, Relative Preferences]; Jennifer Roback, Southern Labor Law in the Jim Crow Era: Exploitative or Competitive?, 5I U. CHI. L. Rev. 1161 (1984); Ronald Turner, Thirty Years of Title VII's Regulatory Regime: Rights, Theories, and Realities, 46 ALA. L. Rev. 375 (1995); Frank McCoy, Rethinking the Cost of Discrimination, BlaCK ENTERPRISE, Jan. 1994, at 54, 57 ("[T]here is no evidence that market competition-in the absence of affirmative-action regulations-will eliminate discrimination."); Clarence Page, Bias Against Bias Law, CHI. TRIB., May 31, 1992, at Tribune Books 5.

38. Posner, supra note 21 , at 513-14. 
to consider the psychic costs imposed by discrimination on its victims. ${ }^{39}$

This failure of perception by the Law and Economics movement is particularly perplexing because the seminal work that first applied quantitative economic analysis to racial discrimination began its analysis by hypothesizing that whites incur psychic costs when they must associate with blacks despite a preference for nonassociation. The logical corollary would suggest that blacks might incur psychic costs or psychic income from the presence or absence of discrimination.

Even more remarkable, the psychic costs to victims of discrimination were overlooked even by defenders of Title VII who challenged the market efficiency arguments of the Law and Economics school. ${ }^{40}$ Nowhere in the longstanding argument between adherents of Law and Economics and civil rights advocates has anyone directly raised this failure. Over more than four decades, in all the subsequent literature, ${ }^{41}$

39. This failure of perception is not unique to Law and Economics but is found in other aspects of the law concerning race. For instance, in City of Richmond v. J. A. Croson Co., the Court wrote, "States and their local subdivisions have many legislative weapons at their disposal both to punish and prevent present discrimination..." 488 U.S. 469,494 (1989). In the context of this statement the Court clearly meant laws against racial discrimination in business transactions. The Court apparently viewed the statement as so obvious it felt no need to cite to any judicial decision or legislative enactment. Yet if the Court (in an opinion written by Justice OConnor) had tried to find a citation, it would have been unable to do so, because no such laws have been enacted anywhere. The Court shares this misperception with many in the civil rights community who similarly assume that remedies exist for such discrimination. For an explanation for the nonexistence of such laws, see Suggs, supra note 7 , at $1264-87$. It is also noteworthy that the dissents in Croson, even the one by Justice Marshall, let the quoted language pass unchallenged.

40. A small sampling of the voluminous literature includes: John J. Donohue III, Is Title VII Efficient?, 134 U. PA. L. Rev. 1411 (1986); Donohue, Further Thoughts, supra note 37; John J. Donohue III, Advocacy Versus Analysis in Assessing Employment Discrimination Law, 44 STAN. L. Rev. I583 (1992) [hereinafter Donohue, Advocacy Versus Analysis] (reviewing EpsteIn, Forbidden Grounds, supra note 26); Palgrave, supra note I, at 6I5. Even critics of the Law and Economics approach to racial discrimination overlooked the psychic costs to victims of discrimination. Professor John Donohue, one of the leading critics of the Law and Economics argument that antidiscrimination laws are unnecessary, also failed to realize that discrimination imposes psychic costs on its victims. His goal of demonstrating that antidiscrimination laws are efficient makes this oversight especially noteworthy. Since discrimination imposes psychic costs on its victims, his strongest efficiency argument would have been to emphasize the psychic costs to victims, especially since in the more appealing moral calculus these costs would be greater to the victims of discrimination. The subjective psychic costs of individuals cannot be directly measured and compared-this was the point of Beckers' methodology to indirectly quantify it. Assuming individuals have fixed preferences of unvarying intensity (a critical assumption of Becker and one inconsistent with the empirical data), a rabid racist willing to murder to preserve his preference for nonassociation might well have greater psychic investments in discrimination than a saintly victim willing to endure, persevere and forgive might have in equality and respect. Yet intuitively it seems there ought to be a significant economic distinction, as well as a moral one, between psychic costs incurred from thwarted preferences for nonassociation and costs imposed by affirmative acts of humiliation and harassment and especially from direct financial costs arising from unequal wages.

41. The sociological and psychological literature has for decades focused on the psychological injury to targets of discrimination. See Brown v. Bd. of Educ., 347 U.S. 483, 494 n. I (I954) (citing K. B. Clark, Effect of Prejudice and Discrimination on Personality Development (Midcentury 
virtually nowhere has anyone considered the psychic costs that discrimination imposes upon its victims. I have identified only five commentators that verged on recognition that victims bear psychic costs, but even the recognition of these commentators was either outside the context of an economic analysis (Alexander ${ }^{42}$ ) or failed to realize the import of their ephemeral insights (Posner ${ }^{43}$ Charney, ${ }^{44}$ Donohue,${ }^{45}$ and McAdams ${ }^{46}$ ).

These costs were as invisible as the protagonist in Ralph Ellison's classic novel. ${ }^{47}$ Yet these costs must necessarily exist. If whites can

White House Conference on Children \& Youth, 1950)) (stating that this is "amply supported by modern authority").

42. Larry Alexander, What Makes Wrongful Discrimination Wrong? Biases, Preferences, Stereotypes, and Proxies, I4I U. PA. L. Rev. 149, 195-200 (1992) (discussing psychic costs as psychological injury in the context of moral claims).

43. Posner, supra note 21 , at $5 \mathrm{Ig}$ (" $[\mathrm{N}]$ et loss of wealth might be offset in gain in self-esteem from being freed from direct... discrimination, but that gain would be outside the scope of the analyses...."). If Posner had been thinking of self-esteem as a psychic loss in Becker's terms ("In Becker's analysis, the costs to whites of associating with blacks are real costs..." Id. at 515), then it would not be outside the scope of analysis.

44. David Charney \& G. Mitu Gulati, Efficiency-Wages, Tournaments and Discrimination: $A$ Theory of Employment Discrimination Law for "High Level" Jobs, 33 HARv. C.R.-C.L. L. REv. 57 (1998).

Within the premises of Becker's model, defenders of legal regulation are left to emphasize the interim costs of waiting for discrimination to be eradicated by market processes - in particular, the psychic harms suffered by victims of discrimination and the social loss that results when discrimination reduces the incentives for a group to work or invest in human capital.

Id. at 63 .

45. Perhaps the most tantalizing mentions appeared in Donohue, Advocacy Versus Analysis, supra note 40 , at $1588-89$. "Private discrimination is a form of psychological pollution that corrodes the well-being of both victims and moralists, and excluding these costs from the social calculus-as Epstein does-would be as illogical as excluding the costs of chemical pollution in assessing environmental programs." Id. at ${ }_{1588}$. "The problem in this context is that any effort by blacks to bribe whites to stop discriminating may generate psychological losses that exceed the gains from eliminating discrimination." Id. at 1589 n.21. "The existence of racial discrimination in labor markets imposes external costs on those, both black and white, who are offended by such invidious discrimination." Id. at 1589 . "[T] he discriminatory firm imposes dignitary harms ... on minority citizens." Id. at I609. See also Stewart J. Schwab, Employment Discrimination, in 3 ENCYCLOPEDIA of LAW AND ECoNomics 572 (B. Bouckaert \& G. De Geest, eds.). Schwab summarizes the argument in Donohue's review of Posner's book:

[T] aking up more directly Posner's challenge to point to a market failure, Donohue pointed to third-party moralists who abhor discrimination directed against others. Their preferences are not considered in the contracts between employers and black and white employees. Even if discriminating employers are willing to pay for their taste for discrimination in reduced profits, the outcome is not efficient because employers are ignoring the external harm their discrimination causes these moralists .... Donohue has acknowledged that economists generally try not to rely on altruism or the preferences of moralists in making efficiency arguments.

Id. at 584 (footnotes omitted).

46. "[T] $]$ he relative preference theory points to an obvious harm of discrimination that is entirely missed by Becker's account: the psychological harm to the victims of discrimination." McAdams, Relative Preferences, supra note 37, at 98.

47. Ralph Ellison, InVISible Man (1947). 
experience costs from their mere inability to satisfy a preference for nonassociation, then surely blacks must incur psychic $\operatorname{costs}{ }^{48}$ when victimized by discrimination.

Becker's argument explicitly considered, and was premised upon, the psychic costs that whites incurred when their preferences for nonassociation with blacks were unsatisfied. Becker devoted individual chapters to the psychic costs borne by white workers, white employers, and white consumers. He developed mathematical equations for all these variants on his central idea. At only two points in his analysis ${ }^{49}$ did Becker partially escape from his one-sided perspective and recognize that blacks could experience psychic costs. But these psychic costs were incurred as "wannabe" perpetrators of discrimination-when blacks wished to discriminate against whites but could not satisfy their preferences for nonassociation - not as victims of discrimination.

If the psychic costs incurred by whites upon denial of their preference to discriminate determine the wisdom and advisability of antidiscrimination laws, then the psychic costs borne by victims of discrimination must have at least equal consideration. To conclude otherwise requires the belief that blacks do not share a common humanity and lack the same feelings as whites.

Such a belief was implicit in Posner's expansion of Becker's approach:

In Becker's analysis, the costs to whites of associating with blacks are real costs, and a law requiring such associations does not, at least in any obvious way, reduce those costs. Of course, it makes blacks better off, presumably by less than it makes whites worse off; for if both whites and blacks were made better off, there would be net gains from association and the law would not be necessary. ${ }^{50}$

Posner appears to mean only that black financial gains from the end of discrimination would be less than white psychic losses from denial of their preference for nonassociation. If black gains exceeded white losses, then blacks could pay whites to give up their preferences and still have net gains. So, ending discrimination would become a mutually beneficial voluntary transaction. However, implicit in his reasoning is the assumption that blacks cannot have psychic costs.

In Posner's analysis, having paid whites to give up their preference, blacks would still be better off than before, when they lacked access to

48. These costs would also affect the incentives for blacks to seek work with discriminatory employers or co-workers or consumers, and no analysis considered how these incentives would affect the predicted ability of market competition to drive discriminatory firms out of business or create market distortions. See Part III infra.

49. BECKER, supra note I, at 3I, I57.

50. Posner, supra note $2 \mathrm{I}$, at 515 (emphasis added). 
the jobs that whites had. ${ }^{51}$ But if black psychic costs are tallied, then besides absorbing the monetary costs of having to bribe whites to work with them, they would still have the additional psychic costs of the humiliation of having had to pay whites for that "privilege." 52

From Posner's perspective, psychic costs are only incurred with the passage of antidiscrimination laws that deny whites their preferences. But when black psychic costs as victims of discrimination are considered, then prior to the enactment of these laws they have both psychic costs from the denial of their preference to be treated with equality as well as the financial costs imposed by discriminatory terms of employment.

Law and Economics has some explaining to do. It hypothesized a white population that realized psychic income from its associational preferences, but failed even to consider that African-Americans might incur psychic losses from those same white associational preferences. Why the flip side of the psychic coin never warranted examination is puzzling. Such a glaring lack of symmetry in the analysis escaped identification over several decades of criticism and rejoinder. It fairly demands explanation. ${ }^{53}$

The methodologies of economic analysis, specifically, the practice of neglecting to explicitly articulate the underlying assumptions of microeconomics, probably contributed to this oversight. Becker analyzed the effects of discrimination by the employers, employees, and customers on an individual firm. His analysis focused on the effects on the individual firm's profitability, caused either by discrimination against more productive African-American workers, which raised firm labor costs and reduced profitability, or caused by not discriminating and

5I. See supra note 24 and accompanying text. This aggregation would not work. Even if an employer were nondiscriminatory, if its white employees were not, the result under Becker's analysis would be monoracial work forces. Posner assumes that the psychic stakes to each side are equal on an individual basis. Consider the integration of Central High School in Little Rock. Thousands of white students felt very intensely about the entrance of nine African-American students into their all white school. Even one student, i.e., James Meredith integrating into Ole Miss, provoked a similar intense reaction. In both instances the aggregate costs required to satisfy white preferences would have dwarfed the aggregate resources of the African-Americans involved, probably even of their entire community.

52. See Donohue, Advocacy Versus Analysis, supra note 40, at $1588 \mathrm{n} .2 \mathrm{I}$ ("The problem in this context is that any effort by blacks to bribe whites to stop discriminating may generate psychological losses that exceed the gains from eliminating discrimination. In other words, the very act of trying to bribe someone to treat you equally underscores your own subordinate role.... Some things of value may simply not be achievable through purchase.").

53. In the grand sweep of American history, this failure of empathy is hardly noteworthy; slaveholders imagined slaves were happy; and modern segregationists believed that only interference from outside agitators generated civil rights protests from an otherwise contented (but impoverished and exploited) African-American population. Of course slaveholders and segregationists were also unabashedly white supremacists whose racial ideology had no problem conceptualizing AfricanAmericans as lacking any desire for personal freedom, autonomy or respect, factors central to the existence of the white population and the foundational theory of our Constitution. 
having to pay greater wages to white workers so they would forego their taste for discrimination. In the first instance blacks are never hired, so black psychic costs do not become part of the cost structure of the individual firm under analysis. In the second scenario, when white employers must forego their preference for nonassociation because black workers are hired, then black workers would have no psychic losses from refusals to hire (although they would have psychic costs from the knowledge that whites were paid more for the same work), but these would not be firm costs. ${ }^{54}$ Within the universe of the individual firm under analysis, black psychic costs do not appear, so perhaps Becker never thought of them. Proponents of Law and Economics then took his finding that discriminatory firms would be less competitive, and concluded that antidiscrimination laws were unnecessary and a dead weight burden on the economy. ${ }^{5 s}$ But, this conclusion ignored the underlying assumptions of Becker's analysis, which was limited to the individual firm. The expansion of his finding from the individual firm level to the general economy and society ignored the psychic costs to victims of discrimination, who became invisible because their psychic costs were external to any individual discriminating firm.

Unfortunately, I can offer no convincing explanations for the decades long persistence of this oversight and my speculation would be no more than that. The identification, description, and analysis of this failure of Law and Economics bespeaks caution to those who would fit complex human behavior within an all encompassing theory while ignoring the limits and frailties of the human animal. ${ }^{56}$

\section{Incorporating Black Psychic Loss in Becker's Model}

What happens to Becker's analysis if the psychic costs of victims of racial discrimination are included? Black workers must incur psychic costs, ${ }^{57}$ and, arguably, much greater psychic costs than whites, ${ }^{58}$ resulting

54. This assumes that white employees and employers do not discriminate in other ways; e.g., terms and conditions of employment, assignments, training, promotions.

55. Becker's work preceded the enactment of Title VII by a decade, so this error cannot be laid at his doorstep.

56. A brain biologist, finding this unremarkable, would point out that the brain evolved in response to environmental challenges to the human animal's survival and not with the goal of perfecting a general purpose reasoning appliance, the equivalent of a biological computer. See generally Joseph E. LeDoux, The Emotional Brain: The Mysterious Underpinnings of Emotional LIFE (1996). On how the biological basis of economic choices at the level of neural circuits in individual brains has given rise to a new field neuroeconomics, see Sandra Blakslee, Brain Experts Now Follow the Money, N.Y. Times, June 17, 2003, at FI. There is even a legal variant, Law and Neuroeconomics. See generally Terrence R. Chorvat et al., Law and Neuroeconomics, Geo. MAson L. \& ECON. Res. PAPER No. 04-07 (Feb. 2004), available at http://ssrn.com/abstract=501063.

57. These are aside from economic costs, e.g., exclusion from the informal information exchange among co-workers that enhances job performance and career planning. In addition, preliminary research suggests a link between the psychological stress of discrimination and hypertension and 
from explicit discriminatory denials of employment, disparate wages, ${ }^{59}$ racial harassment, ${ }^{60}$ overt bigotry, and deliberate acts of humiliation from white employers and employees."

In the standard Law and Economics analysis, black workers must work for lower wages because the reduction in demand for black workers created by discriminatory employers would reduce the total demand for black workers. With the supply remaining constant, ${ }^{62}$ their wages would have to fall. Classic Law and Economics assumed black workers would accept a discriminatory wage, and receive unequal pay for equal work from employers concerned more with profits than a preference for nonassociation.

If Becker's analysis is modified to incorporate black psychic costs, then two major consequences ensue. The first is that the entire economy benefits from the legal prohibitions of Title VII against discrimination. The costs to victims of discrimination (to the extent that prohibition is effective) are eliminated and civil rights laws are not wasteful. Second, absent laws against discrimination, black workers might respond differently than predicted by Law and Economics. They might not go and happily work at other firms for lower wages. Subtracting their psychic losses from their nominal wages could conceivably reduce their wages below zero. Other alternatives might provide greater utility. They might

increased morbidity and mortality. Such a link, if confirmed, translates psychic costs into more traditional economic costs. If debilitating stress is also created for whites merely from functioning in a desegregated environment, then whites who experience this loss (of status according to the McAdams critique), may also experience the psychic costs of being unable to satisfy their preference as the more conventional economic loss of impaired health.

58. See supra note 40.

59. Denials of employment would result from white employer's preference for nonassociation.

60. Racial harassment could result from employment of black workers by discriminatory employers expressing their preference for nonassociation or from white employees expressing a similar preference. Becker assumed perfect competition and the absence of supply constraints for workers of either race, and he argued that white employers would trade their preference for nonassociation for increased profits and employ all black employees at reduced wages, and that such an integrated work force would not occur because white workers would demand more wages to work alongside black workers than to work with other white workers, leading employers to have either all black or all white employees. BECKER, supra note $\mathrm{I}$, at 56 . In a less than perfect world with supply constraints for some workers, employers may find a shortage of one category of white production workers, leading them to hire all black employees in a given category, but there may be an oversupply of white supervisory employees so that white supervising employees may be unable to move to a comparable position supervising white employees. For such a white supervisory employee the quantification of his preference for nonassociation would result in a sum less than the wage differential between supervising black employees and stepping down to a lower category of employment where the shortage exists.

6r. Legal prohibitions are often effective because they establish societal norms, but societal norms favoring antidiscrimination might also exist in the absence of legal prohibitions.

62. This is a reasonable assumption for the short term, but over any extended period of time, the labor supply might change, through migration, emigration, self-employment, or withdrawal from the labor force. 
drop out of the labor force entirely, seek underground employment in illegal activity, or seek employment in different occupations (underemployment) with lower nominal wages but without the psychic losses. ${ }^{6_{3}}$ Or they might become tardy and less disciplined at work. By shirking they might lower their productivity to conform to their reduced wage.$^{64}$ By thus reducing psychic losses, shirking is income maximizing. Since their reduced wages would in turn reduce their returns on their invested human capital, they might have reduced incentives to make future investments in their own human capital ${ }^{65}$ and become less willing to increase their skills by seeking out training opportunities or advanced education or become less willing to use informal networking opportunities to benefit their employer. Each of these possible responses denies to the less discriminatory employer the enhanced profitability that Law and Economics predicts. For these reasons ${ }^{66}$ market competition is unlikely to drive discriminatory firms out of business.

\section{A Suspicious Audience}

Overcoming the racial divides that plague our society requires the creation of business wealth among all disadvantaged groups. Yet before such a goal becomes the priority of the civil rights establishment, the suspicions of this audience must first be overcome. This audience is far from predisposed to consider solutions derived from economic analyses of racial phenomena, or to view business firms as the natural beneficiaries of their labors. Black business development has always been an afterthought, or at best a step-child, in the civil rights agenda. Most political support for such programs has come from Republican administrations, not the Democrats, who, beginning with Franklin Delano Roosevelt, and especially since Lyndon Baines Johnson, have been viewed as more progressive on racial issues. And, AfricanAmericans are overwhelmingly Democratic. The Nixon administration's heraldry of "Black Capitalism" contrasted with the War on Poverty. Robber barons, even black and

63. This means discrimination can affect the distribution of workers, which contradicts Becker's analysis. See BECKER, supra note $\mathrm{I}$, at 3 .

64. A Soviet Russian aphorism captured the low worker productivity response to the low wages of that society, "They pretend to pay us and we pretend to work."

65. Cass Sunstein, Free Markets and Social Justice 157-58 (1997). This is also a response to statistical discrimination and is the response that can make statistical discrimination a self-fulfilling prophecy. See also Peter P. Swire, The Persistent Problem of Lending Discrimination: A Law and Economics Analysis, 73 Tex. L. Rev. 787, 825-828 (1995) [hereinafter Swire, Persistent Problem].

66. See generally Sunstein, supra note 65 . Cass Sunstein and others have identified this disincentive to invest in human capital in rebutting the claim that statistical discrimination is efficient.

67. Shortly after his election, President Richard Nixon established a national program for minority business, in an effort to foster "Black Capitalism," Exec. Order No. I 1 458,3 C.F.R. $\$ 779$ (1969), which created the Office of Minority Business Enterprise (OMBE) in the Department of Commerce. 
embryonic ones, hardly seem deserving of our sympathy or sacrifice.

The personal history of the civil rights leadership created a fertile milieu for suspicions about the business world and the credibility of economic analysis. The civil rights establishment has historically lacked significant ties to the business world. It is alien. None of the national leaders of the I950s and I960s came from business backgrounds. Few African-Americans have achieved positions of leadership within large corporations. ${ }^{68}$ Those that have, only recently, did not succeed by pursuing African-American agendas. African-American owned business firms more firmly grounded in African-American communities remain small and a minor element in African-American society. ${ }^{69}$ Some might also doubt the wisdom of premising the fulfillment of the aspirations of so many on the success of a small group motivated primarily by naked self interest.

Another difficulty derives from the origins of African-American intellectual opinion, which habitually views the world from a non-market perspective. African-American history involves a unique experience with the market. African-Americans were both exchanged as market commodities $^{\text {70 }}$ (a simultaneously harsh and intimate market experience)

68. The first African-American CEO of a Fortune 500 company was Franklin Raines, who was first appointed in January 1999 as CEO of the Federal National Mortgage Association (Fannie Mae). Lynn Norment, New Faces in Executive Suites, Ebony, Jan. 2000, at 42-43. By 2002, Kenneth Chenault at American Express, Richard Parsons at AOL-Time Warner, and Lloyd Ward at Maytag Corp. had also been appointed as CEOs of Fortune 500 companies. Cora Daniels, The Most Powerful Black Executives in America: Meet 50 Black Businessmen and Women Who Wield Unprecedented Clout, ForTuNE, July 22, 2002, at 60, 64-66. Since then, two more have joined their ranks. Stanley O'Neal became CEO of Merrill Lynch \& Co., Inc. at the end of 2002, available at http:/www.ml.com/index.asp?id=7695_8134_8302_13747 and Aylwin Lewis was appointed CEO of Sears Holdings Corp. in 2005, Robert Berner, At Sears, a Great Communicator, Business WeEK, Oct. 31,2005 , at 50, 52.

69. See Part III infra, for an analysis of the size of this business community. What market power African-Americans possess is exercised as consumers, and consumers attempting to act collectively face problems of free riding, bonding, communication, and governance-problems people usually solve by forming governments.

70. Few recognize today the enormous share of national wealth held in slaves. The i 860 Census found total real and personal property of $\$ 16.2$ billion. UNITEd STATES, STATistics of THE UNITEd STATES IN I860, at 295 tbl.2 ( I 866). The capital cost of all slaves in I 860 was calculated as $\$ 2.7$ billion. Claudia Dale Goldin, The Economics of Emancipation, 33 J. Econ. Hist. 66, 73-74 (1973). Therefore, in 1860 slaves represented about $17 \%$ of all the real and personal property within the U.S. The 1860 Census found 3,953,760 slaves representing $89 \%$ of the "Negro" population. Social SCIENCE RESEARCH Council, U.S. Dep't of Commerce, Historical. Statistics of the United States, Colonial Times to I957, Series A, 95-122 (1960). Another study calculated capital in slaves at about $\$$ I billion more or $23 \%$ of all real and personal property in the U.S. Louis A. Rose, Capital Losses of Southern Slaveholders Due to Emancipation, W. Econ. J., Fall 1964, at 39, 40-4I. Several states lost more than 50 percent of all property with emancipation. Id. at $5 \mathrm{I}$ tbl.9. Wealth in slaves freed probably exceeded the South's share of GNP. Id. at 42 . Wealth in slaves represented about the same share of national wealth today represented by corporate equities and mutual fund shares combined or by total pension fund reserves. U.S. Census Bureau, U.S. Dep't of Commerce, Stat. A bstract of the U.S.: 2004-2005, at 458 tbl.695. Household and Non Profit Organizations Sector Balance Sheet: 1980-2003. 
and prohibited from engaging in market activity for their own benefit. ${ }^{7}$ As a result, African-Americans lack a significant business community and have only just begun to develop one..$^{72}$

The absence of a strong business community and the indirect prohibitions on developing one had two consequences. It led to an early reliance on non-market institutions, especially the church, but also including schools and social welfare organizations, both as sources of leadership and as intermediaries to engage dominant white institutions. It also distorted the African-American perspective on society and social change by underemphasizing the roles of business and entrepreneurial activity. Further skewing this perspective, major non-market institutions such as the military, government, and nonprofit social welfare organizations tentatively began employing African-Americans more than a generation before the business community, assuring that the AfricanAmericans most knowledgeable about mainstream institutions remained somewhat removed from the business world. Even during the period of sustained organizational activity that created political coalitions capable of enacting civil rights legislation, only rarely did political allies come from the white business community.

Until comparatively recently, few African-Americans had direct experience as business owners. ${ }^{73}$ Even professional employment in major

71. See, e.g., Ira Berlin, Slaves Without Masters: The Free Negro in the Antebellum South 3I6-40 (I974) (describing laws that discriminated against blacks in the early Igth century); Lorenzo Johnson Greene, The Negro in Colonial New England 298-315 (1968) (describing political, economic, and social barriers imposed on free blacks in New England during the $18^{\text {th }}$ century); A. Leon Higgingotham, JR., In the Matter of Color: Race and the American Legal Process, The Colonial Period (1978) (chronicling various state legal and economic barriers faced by slaves); LeON F. Litwack, North of Slavery: The Negro in The Free States, I790-I860 153-86 (196i) (describing how discriminatory laws and attitudes kept blacks of the North out of commerce, the professions, and skilled occupations); Edgar J. McManus, Black Bondage in the NorTH 172-77 (1973) (explaining how post emancipation laws perpetuated the white hegemony); C. VANN Woodward, The Strange Career of Jim Crow (2d ed. 1966) (detailing segregation known as the Jim Crow system); Flournoy A. Coles, Jr., The Unique Problems of the Black Businessman, 26 VAND. L. Rev. 509, 510-II (1973) (describing several 18 th century laws preventing slaves from carrying on businesses).

72. See Part III, infra.

73. In I982, of the 339,239 Black-owned business firms, only 38,63 I were substantial enough to have paid employees, only 1,129 had receipts exceeding $\$ 1,000,000$; and only 136 employed 100 or more employees. U.S. Census Bureau, U.S. Dep't of Commerce, I982 Survey of Minority-OWned Business ENTERPRISES-Black, at 4 tbl.i, go tbl.9, 92 tbl.ıo (i985). By I997, Black-owned firms had grown in number to 823,499 with 93,235 having paid employees, an increase of $243 \%$ in the number of firms and an increase of $241 \%$ in the number of those with paid employees. Firms with $\$ 1,000,000$ or more in receipts had increased to 8,682 , [Since this threshold is unadjusted for inflation, the increase in part reflects this factor.] and firms with 100 or more employees had grown by $654 \%$. Even with this rapid growth Black-owned firms accounted for only $3.95 \%$ of all firms, $1.76 \%$ of firms with paid employees, and $0.38 \%$ of total business receipts. U.S. Census BurEaU, Dep't of Commerce, 1997 SURVEY of Minority-OWNed Business ENTERPRises - BlaCK, at 17 tbl. I, 75 tbl.8, 77 tbl.9, 80 tbl. I I (200I). Preliminary estimates released from the most recent economic census (2002) show continued growth. Between 1997 and 2002 the number of Black-owned firms increased $45 \%$, and their revenues 
corporations, itself effectively barred until the late 1960s, could not provide a rewarding experience with market institutions. An economic perspective on society, routine for any business owner, did not come bundled with the African-American experience. Amongst neither the elites nor the rank and file would reliance on business as an engine of collective progress have come naturally.

At the same time that Law and Economics became popular among legal academics in the early 1970s, African-Americans first began the desegregation of mainstream legal institutions, especially the law schools. ${ }^{74}$ Many of the first law faculty had first established themselves as lawyers with major civil rights organizations and had spent considerable portions of their careers battling discrimination. To them the sincere belief that civil rights laws were unnecessary and that market forces would extinguish discrimination would have seemed akin to lunacy.

During this period, the Olin Foundation was both funding the establishment of Law and Economics programs at a number of leading law schools ${ }^{75}$ and providing financial support to many of the litigation efforts seeking to invalidate affirmative action. ${ }^{76}$ This common source of support suggested a link between a dominant school of economics and a broader agenda hostile to civil rights.

Furthermore, Becker's analysis, which hypothesized racial discrimination motivated by a desire for nonassociation, flatly contradicted the historical record. In the South especially, during slavery and its Jim Crow aftermath, the most intimate functions of white family life revolved around African-Americans as domestic servants, nannies,

increased $30 \%$, but the number with paid employees increased from 93,200 to 94,862 , less than I. $7 \%$. U.S. Census Bureau, 2002 Survey of Business Owners, Preliminary Estimates of Business OWNERShip by Gender, Hispanic OR Latino Origin, and Race: 2002, available at http://www.census.gov/csd/sbo/ and http://www.census.gov/Press-Release/www/200I/cbor-54.html (last visited Nov. 3, 2005).

74. The first African-American to teach full time at a predominantly white law school, was Willam R. Ming, who taught at the University of Chicago's law school from 1946-1950. By I964 the national total had reached four and by 1973 the total of full time teachers at ABA accredited schools had reached about fifty. Edward J. Littlejohn, Black Law Professors: A Past . . A Future?, Mich. B.J. 538, 540 ( 1985 ). Even earlier, Clarence M. Maloney, "spent 'a review year at ... Buffalo School of Law" in 1925. J. Clay Smith, Jr., Emancipation, The making of the Black Lawyer, 1844-1944, at 4I (1993).

75. The Olin Foundation has supported Law and Economics programs at leading law schools, including Harvard University, University of Michigan, Stanford University, University of Chicago, University of Virginia, University of California-Berkeley, Northwestern University, Cornell University, and Georgetown University. See John M. Olin Foundation, Inc., Schedule of Grants, available at http:/www.jmof.org/grants_1996.html (last visited July 16, 2004).

76. From 1985-2000, Olin gave the Pacific Legal Foundation \$545,000. Lee Cokorinos, The Assault on Diversity: An Organized Challenge to Racial and Gender Justice 94 (2003). "Beginning with its involvement in the seminal 1978 case, Regents of the University of California $v$. Bakke, Pacific Legal Foundation has been in the forefront of anti-affirmative action litigation throughout the entire country." Id. at 89. 
and wet nurses. Even housing patterns reflected this intimacy. Before modern forms of transportation developed and became widely available to the poor, the large number of African-Americans who worked in white households necessarily lived in close proximity to their employers. At the time Becker wrote (1957), the South lacked the strict geographic residential segregation that marked the urban North, a state of affairs taken as a given by Becker. ${ }^{77}$ Even in the urban North, the scale of such segregation was of comparatively recent origins, reflecting the migrations fueled by the industrial expansions of two World Wars. To anyone with a passing acquaintance with African-American or urban history, Becker's hypothesis appeared absurd.

Law and Economics only compounded this absurdity when it pronounced that antidiscrimination laws were unnecessary and wasteful. In the context of the times, the policy recommendations coming from Law and Economics appeared dubious at best, and coming so soon after the first beginnings of desegregation, possibly malign. For later scholars, especially economists who rejected the assumptions underlying Law and Economics, and who might have investigated whether economic analysis could shed new light on racial phenomena, the well had been poisoned.

Even without this "poison" the civil rights community was unlikely to be fertile ground for economic analysis. It had never succumbed to the infatuation with economic analysis and market efficiency that captivated the imagination of so many conservatives. Relatively few senior legal scholars identified with the civil rights community, or sympathetic to it, have used economic analysis as part of their core scholarship. ${ }^{78} \mathrm{~A}$ few

77. MASSEY \& DENTON, supra note 5, at I9-22. "Before 1900, blạcks were not particularly segregated from whites, and although they were overrepresented in the poorest housing and the meanest streets, their residential status did not differ markedly from that of others in the same economic circumstances." Id. at I9. See generally Gunnar Myrdal, An American Dilemma: The Negro Problem and Modern Democracy 279-303 (20th Anniv. ed., 1962). Until the spread of motorized public transportation, commuting was not possible. I am hardly to first to point this out. See McAdams, Cooperation and Conflict, supra note 36, at 1037 (Discussing the theory that some individuals will make material sacrifices for group welfare and will do so for intangible rewards like honor or enhanced esteem. Furthermore, it discusses how employment of African-American help in southern homes rebuts the "desire to avoid contact with blacks."). McAdams analysis has been rejected by adherents to Law and Economics. See Epstein, Status-Production, supra note 37 . The real problem with McAdams' critique, which I otherwise find persuasive, is that the racial status production that he identifies requires a group identity, and microeconomics assumes that the individual is the only relevant unit of analysis, i.e., that groups do not matter. Thus his theory violates a fundamental assumption of his critiques. It is unfortunate that such conflicts in assumptions are rarely articulated and that economic analysis proceeds without first making all assumptions explicit.

78. See, e.g., Richard Delgado, Rodrigo's Roadmap: Is the Marketplace Theory for Eradicating Discrimination A Blind Alley?, 93 Nw. U. L. Rev. 2 I5 (1998):

Beginning with Gary Becker's ground-breaking work in 1957 , law and economics had come to dominate discussion in many areas that $\mathrm{I}$, at least, felt were ill-suited to that form of analysis. Like most humanists, I found something disturbing about applying cost-benefit treatment to phenomena such as human emotions. In particular, I was perturbed by how easily so many accepted that economic analysis could explain the mysteries of human 
specialists in employment discrimination are the categorical exception. ${ }^{79}$ Those sympathizers who have incorporated economic approaches most systematically into their work have been concerned with broader research agendas and the application to racial discrimination has been just a feature or phase of their work. ${ }^{80}$ The major focus of the civil rights community, both within and without legal academe, has remained antidiscrimination and equality jurisprudence. This community has also had little exposure to the competing schools of economics that provide alternative approaches to those of Law and Economics, and whose theories are more in accord with the lived experience of racial discrimination. This situation is slowly changing. A growing number of younger scholars have incorporated economics into their work without wholesale acceptance of the assumptions underlying Law and Economics. $^{81}$

Even fewer scholars (from any discipline) have focused on the barriers confronted by minority business owners. A small body of academic legal literature has developed around the issues faced by lower income communities seeking economic development, and constitutional scholars have examined affirmative action in the context of minority business development, most notably the constitutionality of minority business set-asides. Still, racial barriers faced by minority owned business firms, whether arising from contemporary discrimination or resulting from the legacy of past discrimination, have not been the subject of much interest. Minority entrepreneurs, the immediate beneficiaries of minority business programs and already comfortably middle class, might not inspire sufficient concern. Further, the roots of civil rights activism lie in

nature.

Id. at 218. One singal exception to this lack of interest in economic analysis of discrimination outside the employment context is Ian Ayres, who has also produced empirical as well as theoretical analyses. See Ian Ayres, Fair Driving: Gender and Race Discrimination in Retail Car Negotiations, I04 HaRv. L. Rev. 817 (1991) [hereinafter Ayres, Fair Driving]; Ian Ayres, Further Evidence of Discrimination in New Car Negotiations and Estimates of Its Cause, 94 Mich. L. REv. 109 (1995) [hereinafter Ayres, Further Evidence]. See also Swire, Persistent Problem, supra note 65; Peter P. Swire, Equality of Opportunity and Investment in Creditworthiness, 143 U. PA. L. REv. I533 (1995). Swire applies economic analysis to resolve the dispute between economists skeptical of the survival of lending discrimination in competitive markets and those who document its persistence through empirical research. He finds at least four theoretical economic accounts for why competitive markets may not stop lending discrimination. Both Ayres and Swire have moved on to other research agendas.

79. See generally John J. Donohue III \& Peter Siegelman, Law and Macroeconomics: Employment Discrimination Litigation Over the Business Cycle, 66 S. CAL. L. Rev. 709 (1993); John J. Donohue III, Law and Economics: The Road Not Taken, 22 LAw \& Soc'y Rev. 903, 9I I-I8 (I988).

80. See, e.g., McAdams, Cooperation and Conflict, supra note 36; McAdams, Relative Preferences, supra note 37; Cass R. Sunstein, How Law Constructs Preferences, 86 Geo. L.J. 2637, 2638 (1998); Ayres, Fair Driving, supra note 78; Ayres, Further Evidence, supra note 78; Ian Ayres, Alternative Grounds: Epstein's Discrimination Analysis in Other Market Settings, 3I SAN Diego L. Rev. 67 (1994).

81. See generally Carbado \& Gulati, supra note 3 (reviewing Crossroads, Directions, AND A New Critical Race Theory (Francisco Valdes et al. eds., 2002)). 
social welfare reform and the church. Neither would find a vision of legions of ambitious and well educated minority entrepreneurs becoming extravagantly rich (and voting accordingly) an appealing inducement for self-sacrifice. Given the competing claims on the resources and attention of public interest activists, family dysfunction, inadequate health care and education, high rates of incarceration and unemployment, among many other issues, minority business might not seem to warrant high priority. Yet until minorities have prosperous business communities, filled with financially successful Babbits ${ }^{{ }^{2}}$ who their writers can satirize, true equality will remain a mirage.

While such a claim might appear self evident, the significance of minority business wealth is often overlooked. Besides dramatically increasing the public and private resources available to address our society's failings, it also provides access for minorities to the nongovernmental corridors of power. The pursuit of business wealth is not some version of "trickle down" economics. ${ }^{83}$ The economic consequences of achieving business parity equate not to a few raindrops but to a torrential downpour.

\section{The Importance of Business Wealth}

To be a poor man is hard, but to be a poor race in the land of dollars is the very bottom of hardships. ${ }^{84}$

The Founding Fathers placed considerable faith in the institution of private property as the foundation of liberty. ${ }^{85}$ African-American leaders in the early twentieth century recognized this too. Both Booker $T$. Washington and W.E.B. Du Bois sought to foster business ownership. ${ }^{86}$ Neither foresaw that the ultimate success of their efforts to desegregate American society would as a byproduct destroy the then existing

82. Sinclair Lewis, BabBit (Bantam Classics 1998) (1922).

83. "One economist defines it as 'A theory of economic development that claims higher standards of living for the poor will develop gradually [with economic growth] and not at the overt expense of the more affluent."' WIKIPEDIA, at http://en.wikipedia.org/wiki/Trickle_down_economics (last visited Nov. I I, 2005).

84. W.E.B. Du Bois, The Souls of Black Folk 20 (Fawcett Publ'ns I96i) (I907).

85. "Property must be secured, or liberty cannot exist." James W. Ely, JR., The GUaRdian of Every Other Right: A Constitutional History of Property Rights 43 (2d ed. I998) (quoting John Adams, Discourses on Davila, in 6 The Works of John Adams 223, 280 (Charles Francis Adams ed., 1851); The Federalist No. 54 (James Madison). "The framers of the Constitution were men to whom the right to hold property was enormously important .... Property was seen not as opposed to liberty, but indispensable to it; for men with property would be independent of the power of the State ...." David Ladd, The Harm of the Concept of Harm in Copyright, $3^{\circ}$ J. CopYrighr Soc'y OF THE U.S.A. 42I, 426 (1983).

86. Scott L. Cummings, Community Economic Development as Progressive Politics: Toward a Grassroots Movement for Economic Justice, 54 STaN. L. REv. 399, 4IO-I2 (200I). The two leaders collaborated in the formation of the National Negro Business League. Mark Bauerlein, Washington, Du Bois, and the Black Future, WiLson QuarTERLY, Autumn 2004, http://wwics.si.edu/index.cfm? fuseaction=wq.print\&essay_id $=96415 \&$ stoplayout $=$ true. 
African-American business community. ${ }^{87}$ The desegregation of public accommodations in 1964 caused a sudden collapse of the racial trade barriers in public accommodations. ${ }^{88}$ It exposed the tiny cadre of AfricanAmerican business firms, accustomed to operating personal service and retail trade firms sheltered by rigid segregation from competition with the white mainstream, to an onslaught of competition for their most affluent customers from far larger mainstream firms, with national brands, more convenient locations, economies of scale, better technology, and much deeper pockets. Rapid decline ensued. ${ }^{89}$

Few of these firms, established to exploit and nurtured by segregated markets, have survived and prospered. Instead, African-American firms equipped to thrive and grow in a desegregated marketplace have tended to be new ventures, established by a new class of entrepreneurs. They lack not only established business networks, and often working capital and experience, but they also lack any legal protection from racial discrimination in a society where race still matters. Yet over the past several decades this new group, most of which is in wholesale trade or business services, economic sectors where previously black-owned firms were extremely rare, has grown much faster than the overall economy. Until recently the decline of traditional firms, previously supported by segregated markets in retail trade and personal services, had obscured their growth. Despite rapid growth, because they start from such a small base these newer firms have not yet become a significant factor in the economy.

Yet, without the existence of a successful business community, existing on a continuum in size and sophistication from Wall Street to Main Street, how can anyone claim the playing field has been leveled? Substantive racial equality requires a rough parity of resources in all the arenas of power, including the media, the military, government, politics, academe, and particularly business, the source of the privately controlled wealth essential to influence in most of the other venues.

Between 1970 and 1990 median black household incomes hovered near $60 \%$ of median white household incomes. ${ }^{90}$ During the decade of

87. Timothy Bates, Urban Economic Transformation and Minority Business Opportunities, 13 Rev. Black Pol. Econ. 21, 28-32. The African-American business firms provided goods and services to African-American consumers that whites would not provide because the provision would have contradicted the racial status hierarchy imposed by segregation and the reigning ideology of white supremacy. See generally Timothy Bates, Race, Self Employment and UpWard Mobility (I997).

88. Voting Rights Act, Pub. L. No. 88-352, 78 Stat. 243 (1964) (codified as amended at 42 U.S.C. $\S \S 2000 a-2000 h$ (1988)).

89. Bates, supra note 87, at 28-32; Robert E. Suggs, Recent Changes in Black-Owned Business 2526 (Joint Center for Political Studies, Working Paper, I986).

9o. U.S. Census Bureau, U.S. Dep't of Commerce, Stat. Abstract of the U.S.: 200I, at 443 tbls.66r \& 662 [hereinafter STAT. AbSTRACT of THE U.S.: 200r]. The ratios computed from tabular data were: $1970-60.9 \%$; $1980-57.6 \% ; 1985-59.5 \% ; 1990-59.8 \% ; 1995-62.6 \%$. This data set understates the 
the 1990 prosperity brought a small but steady rise to $65.7 \%$ by $1999{ }^{91}$ but it dropped to $64.4 \%$ by $2002,{ }^{22}$ the most recent year for which data is available. To achieve parity, black household incomes must increase by more than one-half. Large as that gap is, however, the disparity in wealth dwarfs this disparity in incomes. The wealth (median net worth) of white households exceeds that of black households by five to ten times. ${ }^{93}$ At higher levels of wealth, the disparity only increases. Four percent of white households have net worths exceeding $\$ 500,000$, twenty times more than the respective percent of Black households $(0.2 \%) ;{ }^{94}$ and because high wealth households are greatly undercounted, this census data understates the disparity. ${ }^{95}$

Business participation rates reflect the same magnitude of disparity as wealth data. Of all the major minority groups in American society, African-Americans have the lowest business participation rate, engaging in self-employment at between one-quarter to one-third the frequency of

size of the true disparity for at least two reasons; the data on money incomes of households excludes capital gains, $i d$. at $414-15$, of which the wealthy tend to receive a disproportionately large share, and because (given current income distributions) the medians underweight the impact of the extremely wealthy; and blacks are underrepresented among the wealthy. Arthur B. Kennickell, $A$ Rolling Tide: Changes in the Distribution of Wealth in the U.S., I989-200I 34 (Levy Economics Institute, Working Paper No. 393, 2003) (showing that in $200 \mathrm{I}$ the share of non-Hispanic white families with wealth exceeding $\$ 500,000$ was 7.6 times that of African-American families).

91. Stat. Abstract of the U.S.: 2001, at 443 tbls.661 \& 662; see also U.S. Census Bureau, U.S. Dep't of Commerce, Stat. Abstract of the U.S.: 2002, at 436 tbls.657 \& 658 (Including data from 2000 , the median income level of African-American households achieved $64.2 \%$ of that of the median income level of white households by 2000.).

92. U.S. Census Bureau, U.S. Dep't of Commerce, Stat. Abstract of the U.S.: 2004-2005, at 443 tbl.665.

93. Michael E. Davern \& Patricia J. Fisher, U.S. Census Bureau, U.S Dep't of Commerce, Household Net Worth and Asset Ownership: i995, The Survey of Income and Program Participation, at 2 tbl.i (I995) [hereinafter Net Worth and Asset OWNership: I995] (\$49,030 to $\$ 7,073$ or seven times); T.J. Eller \& Wallace Fraser, U.S. Census Bureau, U.S. Dep'T of Commerce, ASSET OWNERSHIP OF Households: 1993, at 9 tbl.F (1993) [hereinafter Asset OWNERSHIP OF Households: 1993] (\$45,740 to $\$ 4,418$ or ten times in I993 and $\$ 47,075$ to $\$ 4,844$ or ten times in I99 I (in I 993 dollars)); Arthur B. Kennickell, et al., Recent Changes in U.S. Family Finances: Results from the ig98 Survey of Consumer Finances, Fed. Reserve Bull., at 7 tbl.3 (2000), available at http://www.federalreserve.gov/pubs/bulletin/200o/ooindex.htm (comparing the family net worth of White non-Hispanics to non-White or Hispanic, $1989,90.5 / 8.5 ; 1992,79.5 / 13.7 ; 1995,81.2 / 16.8$; I998, 94.9/16.4 in thousands of 1998 dollars).

94 Net WorTh AND Asset OWNERShip: 1995, supra note 93, at 7 tbl.4. Mean net worth shows lesser multiples but much greater absolute magnitudes. Median wealth survey data is considered less skewed by the few observations for high income households. The Census survey found only forty-four percent of the aggregate wealth measured by the Federal Reserve survey. ASSET OWNERSHIP OF HousEHOLDS: I993, supra note 93, at 2. Only at death is there an obligation to report total wealth to governments for purposes of state and federal estate taxes. In the interim, many assets virtually unique to the wealthy, e.g., jewelry, antiques, art collections, etc. appreciate over time and except for purposes of insurance or divorce are never reappraised for their fair market value. Even the appreciation of real estate and securities is unrecognized until these assets are sold.

95. The U.S. Census Bureau survey found only forty-four percent of the aggregate wealth measured by the Federal Reserve survey. ASSET OwnERSHIP OF HouSEHOLDS: I993, supra note 93, at 2. 
the overall population. ${ }^{96}$ This rate has barely changed in the seventeen years between the I980 decennial census and the I997 Survey of Minority-Owned Business Enterprises.97 The selection of majors by African-American college students indicates a growing interest in business, but this indication does not differentiate between those seeking jobs with business firms and those planning to become entrepreneurs. ${ }^{98}$ Nonetheless, recent data reveal a significant emerging trend of successful entrepreneurship.

The Census Bureau's Survey of Minority-Owned Business Enterprises (SMOBE) contains the most comprehensive data base for minority business activity. In the ten year interval from 1972 (the first year in which a full census was conducted) to 1982 , the number of paid employees $^{99}$ with Black-owned firms increased by less than $13 \% .^{100}$ In

96. Frank A. Fratoe \& Ronald L. Meeks, Minortty Bus. Dev. Agency, U.S. Dep't of Commerce, Business Participation Rates of the Fifty Largest U.S. Ancestry Groups: Preliminary Report 4, 6 (June 1985). The national business participation rate of 48.9 self-employed persons per Iooo was nearly four times the sub-Saharan African rate of 13.6. Minority Business Development Agency, U.S. Dep't of Commerce, The State of Minority Business, 1997 Survey of Minority-Owned Business Enterprises (SMOBE), at il tbl.9 (rev. Sept. 5, 200I) [hereinafter State of Minority BusinEss, 1997.] This study found a national business participation rate of seventy-eight, a nonminority rate of ninety-one, and an African-American rate of twenty-four.

97. STATE OF MinORITY BUSINESS, 1997, supra note 96, at I I tbl.9.

98. Between $198 \mathrm{I}$ and 1990 the annual number of African-Americans earning bachelor of business degrees increased from around 13,000 to 15,500 , and the number earning master of business degrees increased from about 2,400 to 3,300. Vital Signs: The Statistics That Describe the Present and Suggest the Future of African Americans in Higher Education, J. Blacks IN Higher Educ., 29, 37 (Winter 1993-1994).

99. Paid employment best captures the growth of these firms because the usual measure, revenues, requires continual adjustment for inflation. Employment also shows the effects of business activity on employees, a much larger group than the number of business owners. Everything else being equal, minority firms tend to have greater proportions of minority employees than non-minority firms, but the racial composition of these employees is not the focus of this analysis. African-American business owners who employ large numbers of nonminorities may have more cultural significance for our society than those whose labor force is largely minority.

I0o. Growth in numbers of employees:

$$
\begin{aligned}
& I 972-I 47,184 \\
& I 977-I 64,177 \\
& I 982-I 65,765 \text { (Restated as I } 21,373 \text { in I } 987 \text { census publication to conform to then } \\
& \text { current criteria, which excluded all corporations except subchapter } S \\
& \text { firms.) } \\
& \text { I987-220,467 } \\
& \text { I992-345,193 } \\
& \text { I997-7I8,34I (Survey criteria revised to include all corporations including C } \\
& \text { corporations. Excluding all corporations but } S \text { corporations, the total } \\
& 2002-770,746
\end{aligned}
$$

U.S. Census Bureau, U.S. Dep't of Commerce, Survey of Minority-Owned Business Enterprises, i972: Black, tbl.1 (1972); U.S. Census Bureau, U.S. Dep't of Commerce, Survey of MinorityOWned Business Enterprises, i982: Black, tbl.i (i985); U.S. Census Bureau, U.S. Dep't of Commerce, Survey of Minority-OWned Business EnTERPrises, i987; Black, tbl.i (i990); U.S. Census Bureau, U.S. Dep't of Commerce, Survey of Minority-OWned Business Enterprises, I992: 
contrast, during the fifteen years between 1982 and 1997 , paid employment with Black-owned firms expanded by $333 \%$. ${ }^{\text {Ior }}$ In the next five years, which includes the bursting of the internet bubble, employment at Black-owned firms increased only $7.3 \%$ (I997-2002) virtually the same total gain as for the entire economy $(7.2 \%){ }^{102}$ While such rapid growth provides grounds for optimism about the future, unless this trend continues unbroken for decades, celebration would be premature. (In addition, some of this growth may be an artifact of the survey methodology used.) ${ }^{\text {I03 }}$ At present, African-Americans comprise twelve percent of the population, but employment with AfricanAmerican owned firms still constitutes less than one percent of all employment by U.S. firms. ${ }^{104}$

Data on gross business receipts reveal the same picture. Less than half of one percent of all business receipts derive from Black-owned firms. ${ }^{105}$ While miniscule, this share has doubled since $1982 .{ }^{106}$ If this rapid

Black, at 9 tbl.i (1996); U.S. Census Bureau, U.S. Dep't of Commerce, Survey of Minority-Owned Business ENTERPrises, 1997: Black, at 17, 74 tbls.i \& 7 (2001). U.S. Census Bureau, U.S. Dep'T of Commerce, 2002 Survey of Business OWners, Preliminary Estimates of Business OWnership by Gender, Hispanic or Latino Origin and RaCE: 2002, available at http://www.census.gov/csd/sbo/ sector/secoo.htm.

ior. U.S. Census Bureau, U.S. Dep't of Commerce, 1997 Economic Census: Survey of Minority-OWNed Business Enterprises, Black 9 (200I) [hereinafter 1997 Economic Census: Survey of Minority-OWNed Business Enterprises] (The total in 1997 was 718,341 .); U.S. Census Bureau, U.S. Dep't of Commerce, 1982 Economic Census: Survey of MinortTy-OWned Business ENTERPRISES, BLACK, at 4 tbl.I (1985) (The total in 1982 was 165,765 ).

i02. U.S. Census Bureau, U.S. Dep't of Commerce, 2002 Survey of Business OWners, Preliminary Estimates of Business OWnership by Gender, Hispanic or Latino Origin and Race: 2002, available at http://www.census.gov/csd/sbo/sector/secoo.HTM.

I03. The Census Bureau has struggled to accurately count $C$ corporations, often the largest and most sophisticated business ventures, because these corporations have no Social Security Administration identifiers filed with their tax returns. Pass-through entities (sole proprietorships, partnerships, limited liability companies, and subchapter $S$ corporations), whose income is taxed directly to owners, report social security numbers of owners, allowing racial identifiers in social security records to identify minority-owned firms. In the census for the years 1987 and 1992 the survey did not include C corporations. U.S. Census Bureau, U.S. Dep't of Commerce, Survey of MinorityOWned Business EnTerprises, 1987: Black at iv, vi (1990); U.S. Census Bureau, U.S. Dep't of Commerce, Survey of MinortTy-OWNed Business Enterprises, I992: Black, at v, vii (1996).

104. Total employment in 1997 with U.S. firms was 103,359,815. 1997 Economic CENSUS: SURveY of Minortry-OWNed Business EnTERPrises, supra note ior, at 8 a tbl. I I. While some business firms are so large and old that their institutional character might argue against their having a racial character to their ownership, even if we eliminate all firms with 500 or more employees, Black-Owned firms still employ only $1.5 \%$ of the total. $I d$. at 92 , tbl.I5 (Firms with 500 or more employees had $50,086,736$ employees.). Firms without paid employees (those to which only owners or independent contractors provide services), while far more numerous (Of 823,499 Black-Owned firms in 1997, only 93,235 had paid employees. $I d$. at $\mathrm{I} 7$, tbl.I) than those with paid employees, comprising eighty-eight percent of all Black-Owned firms, averaged gross receipts of only $\$ 20,317$, which after subtracting expenses would be far too little to support anyone. The vast majority of these firms without employees probably represented part-time efforts ancillary to the owner's main source of income as an employee of some other entity.

105. Id. at 17,90 tbls. I \& 14 . The proportion of receipts from Black-Owned firms is $0.38 \%$. 
growth rate, doubling market share every fifteen years, continues for another seventy-five years, only then would this share of business receipts reach the proportion of African-Americans in the total population.

\section{The Social and Political Benefits of a Sizeable Business Sector}

In the world's largest and richest market economy, AfricanAmericans and other minorities ${ }^{\text {107 }}$ cannot participate as equals unless they too can deploy the private power generated by the control and ownership of substantial business assets. The ability to grant or deny desirable jobs and contracts extends influence far beyond the boundaries of particular business firms. Campaign contributions, offers of attractive employment opportunities and profitable business transactions can serve as currency to cement the implicit and explicit bargains that create mechanisms of private social control and allow business communities to influence and even dominate political leaders. Greater financial resources would also enhance the ability to fund special interest lobbying and extend political influence beyond turnout at the polling booths. Such private power is often exercised beyond either the public scrutiny or accountability demanded of public elected or appointed officials and it can serve broader purposes than the "public purposes" governments must dedicate their resources.

If African-American communities had a thriving private sector and business class, their wealth would ameliorate many of the persistent economic racial disparities in employment, income, and wealth. High and increasing rates of incarceration plague low income African-American communities. African-Americans without criminal records are viewed as less desirable than whites with such records. ${ }^{109}$ African-American exoffenders face nearly insurmountable barriers. Potential employers of the same race might share sufficient personal networks of family and friends that the private information available to them might allow them to make more accurate judgments about rehabilitation and be more willing to employ them. Fragmentary data suggests that "minority owned firms are nearly twice as likely to accept ex-felons as are employers in general,"10 suggesting either that they have information about these employees unavailable to other employers, or that they accept higher degrees of risk of employee misbehavior.

106. Suggs, supra note 89 , at 6 .

107. The business activities of other minority groups show a wide dispersion. Asian-Americans, despite large variations among their different groups, on average match the profile of nonminorities, while Hispanics by most measures are about midway between nonminorities and African-Americans.

108. See Wilson v. Conn. Prod. Dev. Corp., 355 A.2d 72 (Conn. 1974).

I09. See infra note 124.

I 10. Margaret C. Simms, Ex-Felons Face Major Economic Obstacles, Focus, May-June 2004, at 7 , 8. 
A lack of private decision-making authority in most areas of the economy even limits the influence that African-Americans have achieved in the public sectors of politics and government. While political commentators decry the influence of money on politics, a paucity of financial resources to compete in money driven electoral campaigns creates a serious disadvantage for black elected officials. Many must negotiate the conflicting desires of a working class and low income electorate, while simultaneously raising campaign funds from the mainstream business community.

Increased African-American business ownership would increase social cohesion and strengthen other intangible factors " that help political communities thrive. It would enable all groups to experience each other in new roles. When African-American entrepreneurs interact with other business owners as valued customers, suppliers, or sources of financing, old stereotypes are challenged and new images are created. Business networks are also social networks.

African-American ownership of media firms could, through programming choices and news coverage decisions, expand the boundaries of public discussion by drawing the public's attention to critical issues. Increased wealth would sustain philanthropic and charitable organizations, which could meet many social service and cultural needs without having to rely on the political process or subjecting itself to public sector constraints. Charities can pursue goals chosen by a minority faction within a political community when it cannot achieve sufficient consensus to become a majority and gain access to public resources. More equal wealth would reduce the social significance of segregated neighborhoods. ${ }^{\text {II2 }}$ De facto segregated schools become an altogether different phenomenon when supported by a substantial tax base and attended by students from families whose affluence assures the advantages that resources provide. The persistence of discrimination may prevent achievement of complete equality across all measurable dimensions, but increased ownership of business assets would reduce many disparities.

Given the improvements in legal, political, social and economic status achieved by the antidiscrimination legal strategies of the civil rights movement, further gains in business ownership will likely continue even while levels of discrimination remain significant. Black business activity has grown despite the legacy of past discrimination and current racial barriers. Existing prohibitions against discrimination in

II I. See generally William Julius Wilson, The Truly Disadvantaged $20-62$ (1987).

112. Douglas S. Massey and Nancy A. Denton found a high degree of residential segregation at all income levels. MASSEY \& DENTON, supra note 5, at $83-88$. This suggests that little segregation results from average racial income differentials. 
employment, public accommodations, housing, and education will have desirable if indirect effects on business wealth. But rather than resting on these achievements, we should seek to accelerate the scope and sophistication of business activity. To do otherwise wastes enormous amounts of human potential, and exposes American society to the risk that intervening events might interrupt such improvements and exacerbate our racial divisions. The private power exercised by business owners and business firms is essentially economic power, and it impoverishes any discussion of the acquisition and development of such power to exclude or ignore the concepts, insights, and methods of the many different schools of economic thought.

\section{Economic Analysis of Racial Phenomena}

Equal protection doctrine no longer provides a useful lens through which to examine race or remediate racial inequities in American society. It once did. When laws classified and mandated by racial categories and imposed burdens and recognized privileges to ensure white supremacy, racially motivated decisions were clear and unambiguous. The line drawing and formulaic approaches of equal protection doctrine made sense. Yet today few explicit and unambiguously malign racial classifications continue to operate. Race with its evolving social and psychological facets has become a slippery, nuanced concept. ${ }^{113}$ Its effects are often opaque both to those affected by and those making the decisions. It often influences decisions in murky and amorphous ways, leaving no single motive standing out as obviously determinative.

On occasion, economics has provided illuminating insights into racial phenomena. One classic gem by Thomas Schelling, ${ }^{114}$ an economist who has written little else about racial phenomena, modeled the impact on housing segregation if blacks and whites had different preferences for degrees of integration for their neighborhoods, and each wished to avoid being part of a small minority. The results are striking. His model shows that even if both groups will accept significant levels of integration, the only stable arrangement will be nearly complete segregation. One counterintuitive implication of this analysis is that high degrees of segregation do not necessarily reflect high levels of racial intolerance.

I13. The debate over whether race is a valid scientific category has still not been resolved. See Nicholas Wade, Two Scholarly Articles Diverge on Role of Race in Medicine, N.Y. Times, Mar. 20, 2003, at A30. At least the debate now seems cast in terms of whether race is a biologically meaningful concept in the context of population groups. This is an improvement from the earlier controversy when racial categories carried biological destiny for particular individuals. See also Jonathan Kahn, How a Drug Becomes "Ethnic": Law, Commerce, and the Production of Racial Categories in Medicine, 4 Yale J. Health Pol'y L. \& Ethics I (2004) (analyzing how patent claims and ethnic niche marketing combined to revive claims of race as biologically based).

i 14. Thomas C. Schelling, Micromotives and Macrobehavior i37-55 (i978). 
While this model was simple and could not incorporate many factors affecting turnover in residential neighborhoods, it illustrated dynamics of racial turnover and resegregation, fueled not by raw bigotry, but merely a desire to avoid racial isolation.

The policy implications of Schelling's analysis are troubling for the equal protection model of racial discrimination fueled by racial animus. Eliminating racial discrimination by real estate intermediaries (sales agents, mortgage brokers, insurers, etc.) from housing markets will not automatically create stable integrated neighborhoods. Neither will the resulting segregated neighborhoods reflect the aggregate desires of the individuals involved. Instead, the results might please no one. Unfortunately, changing the resulting patterns that might satisfy no one requires the coordination of many individual decisions. Accomplishing such coordination would typically involve race conscious governmental actions or market interventions by private organizations, and these might run afoul of current equality laws or antitrust prohibitions. ${ }^{115}$ The essential benefit of such an analysis is to suggest that more than racial animus fuels residential segregation.

In two other contexts blaming racial animus for racial discrimination in real estate markets falls short as a complete explanation. Data on residential segregation shows that it persists at high levels, for all income groups, especially for African-Americans. Housing audits show that real estate sales agents "steer" African-American and Hispanic buyers to specific racially identifiable geographic areas even when these areas do not meet their declared preferences. The standard analysis assumes that racial bias among sales agents accounts for such practices. No doubt this is true in some cases, but as an explanation it is inadequate because it fails to answer a critical question.

Consider a major metropolitan region with a sizeable black middleclass and a documented history of racial steering. Rather than litigate fair housing claims in an attempt to reduce this practice, why is it not possible to just obtain a real estate license, publicize the discriminatory steering practices of one's competitors, announce one's own refusal to steer, and then collect commissions from minority buyers seeking to avoid being steered? Since no one pursues this business model, and there are plenty of minority agents around (presumably some of whom are unbiased), more than simple racial bias must account for the practice of steering. Any agent, black or white, who wants to maintain a profitable business must probably accommodate herself to steering, whatever their personal

I I 5. See generally South Suburban Hous. Ctr. v. Greater S. Suburban Bd. of Realtors, 935 F.2d 868 (7th Cir. 199I); Mark W. Zimmerman, Note, Opening the Door to Race-Based Real Estate Marketing: South-Suburban Housing Center v. Greater South Suburban Board of Realtors, 4I DEPAUL L. REV. I27I (1992). 
values. The market must somehow demand steering.

A similar anomaly exists in credit markets. The Community Reinvestment Act attempts to obligate banks to lend in the neighborhoods in which they locate offices. It seeks to prevent the practice known as redlining, in which lenders refuse credit to minority communities. Denials of credit can have a devastating impact, creating perverse incentives for property owners to defer or eliminate maintenance, and reducing wealth and general economic activity by eliminating a primary source of collateral and capital appreciation. The assumption underlying the Act is that banks or bank personnel refuse credit because of prejudice. But redlining creates business opportunities for other lenders if the markets that are starved have the potential to be profitable. Minority owned community banks could be formed or could expand to serve such markets. If they do not, then something about the market either creates a barrier to their expansion or reduces profitability below alternative opportunities. Without an accurate diagnosis, we cannot fix the problem, we can only fail repeatedly at correcting the wrong problem.

\section{The EfFects of Racially Informed Decisions}

Microeconomics has developed a number of approaches to analyzing racial discrimination. ${ }^{116}$ Only two have received much attention from legal academics. The first, developed by Gary Becker and discussed previously, attributes motives for discrimination to a preference for nonassociation. The second ascribes discrimination to a rational use of racial stereotypes to avoid the increased information costs necessary to acquire individualized information rather than to any malign motive. Becker's preference model contradicts the historical record, but at least it allows the potential irrational element of prejudice to fuel discrimination because the sources of preferences are outside the model. The concept of statistical discrimination, with its emphasis on rational stereotypes, denies that centuries of the well documented ideology of white supremacy used until the contemporary era to justify slavery and Jim Crow had any information effects. ${ }^{17}$

I16. For a summary of the many economic perspectives on racial discrimination, see Economics and Discrimination, supra note 37, at xxvii-xxxii (a two volume collection of reprinted articles on this general topic). In the introduction, Darity summarizes and briefly critiques some of the alternative economic motives for discrimination developed by economists.

I 1. Contemporary accounts overlook the prevalence of white supremacy doctrines in elite circles:

In a response to the Brown v. Board of Education decision ordering the nation's public schools desegregated, William F. Buckley Jr.'s guidebook to conservative thought, National Review, declared the following in the summer of 1957: 'The central question that emergesand it is not a parliamentary question or a question that is answered by merely consulting a catalogue of rights of American citizens, born Equal-is whether the White community in the South is entitled to take such measures as are necessary to prevail, politically and culturally, in areas where it does not predominate numerically? The sobering answer is 
As a concept, statistical discrimination implicitly assumes that enactment of the 1964 Civil Rights Act caused an instantaneous and complete change of heart in the white population, even among those who opposed its enactment most vehemently. It ignores what we know about both the human personality and a culture's resistance to change, ${ }^{118}$ and even our cognitive function. ${ }^{119}$

A more plausible analytical model for discrimination would recognize that while stereotypes may incorporate generalizations with varying degrees of accuracy, race also projects irrational elements into decisions. Race is information, but its use as information is often far from perfectly rational. Race can corrupt decisions in a number of ways that might lead to systematic errors.

First, statistical discrimination claims to describe a rational phenomenon because its racial stereotypes substitute for more individualized information that is either unavailable or more costly to obtain. ${ }^{120}$ The more psychologically plausible claim is that the presence of race in the information mix leads to systematic pessimistic errors in estimates of both the degree of availability and the acquisition cost of more individualized information. ${ }^{121}$ Second, information about racial

Yes-the White community is so entitled because, for the time being, it is the advanced race....'

Bob Herbert, Op-Ed., Recalling An Ugly Time, N.Y. Times, Feb. 24, 2003, at AI7.

I18. It also incorporates the consequences of prior discrimination as its justification for continuing "rational" discrimination.

I19. Testifying to the power of information about race, social scientists have for decades sought to construct experiments in which subjects would not notice a person's race. Only recently has this been achieved. See, e.g., Leda Cosmides, John Tooby \& Robert Kurzban, Perceptions of Race, TRENDS IN Cognitive SCIEnCES, Apr. 2003, at 173-79.

Until recently, it appeared that race-along with sex and age-was encoded in an automatic and mandatory fashion. The encoding of race was thought to be spontaneous and automatic because the pattern of recall errors that indicates race encoding occurred in the absence of instructions to attend to the race of targets, and across a wide variety of experimental situations. It was thought to be mandatory-encoded with equal strength across all situations-because every attempt to increase or decrease the extent to which subjects encode the race of targets had failed.

Leda Cosmides \& John Tooby, Knowing Thyself: The Evolutionary Psychology of Moral Reasoning and Moral Sentiments, Bus., ScI., \& ETHICs, Mar. 2004, at 91, 116.

120. See EPSTEIN, supra note 26 , at 59-87. Epstein analyzes the rational use of discrimination to reduce firm governance costs. Firm homogeneity reduces conflicts among individuals within the firm and facilitates communication and cooperation. Id. Of course, this assumes that sorting by race also correlates with sorting by the relevant factors, i.e. class, region, religion, gender, political values, etc. that produce the desired homogeneity. While such practices may reduce the governance costs within the firm, they may also misallocate society's human capital and thereby increase opportunity costs for society as a whole.

121. See Amos Tversky \& Daniel Kahneman, Judgment Under Uncertainty: Heuristics and Biases, SCIENCE, Sept. 27, 1974, at I I24. Their heuristics of "representativeness" (in which the probability that object A belongs to class B is evaluated by the degree to which A resembles B), and "availability" ("in which people assess the frequency of a class or the probability of an event by the ease with which instances or occurrences can be brought to mind") would seem to have implications for interracial interactions. Id. at I I 24-27. The representativeness heuristic suggests that when racial stereotypes are 
identity in a culture still struggling with its legacy of white supremacy might increase the uncertainty involved in the interpretation of other information. In this latter circumstance, information about race undermines the decision maker's confidence in the reliability or accuracy of other information or increases the uncertainty of inferences drawn from that information. For instance, credentials held by AfricanAmericans are often undervalued when compared to the same credentials held by whites. Some would blame this disparate valuation on affirmative action programs, but the same differential valuation phenomenon was common before such programs existed and persists even in the absence of such programs. ${ }^{22}$ The greater perceived unreliability or uncertainty creates an incentive to acquire more information, which is costly and can lead to the selection of an alternative and cheaper choice not burdened with racial information. ${ }^{123}$ Third, race can corrupt the judgment of decision makers without their realizing it, and in contrast to the second category, cause errors to be made without undermining confidence in the decision or creating ambivalence about the inferences drawn. ${ }^{124}$ In this instance, race (as

cognitively present, even those with some statistical validity, decisions will ignore base rate frequencies and be insensitive to sample size. Id. at II 24-25. The availability heuristic confuses the easy retrievability from memory with the frequency of occurrence and strong stereotypes, being easily recalled, will be judged more statistically frequent than warranted. $I d$. at i 127 . This latter heuristic also results in biases of imaginability when assessments of frequency must be constructed from imagination and are not stored in memory. Id. at I I27-28. People evaluate frequency or probability from the ease of imaginability, which do not necessarily reflect frequency. $I d$. Thus imagining an African-American in a given role of competence may be difficult and thus judged infrequent even though the frequency of actual occurrence is greater.

122. The difficulty that extremely successful African-American quarterbacks experienced trying to continue playing at that position when moving from high school to the college ranks, or from there to the professional leagues, illustrated this phenomenon and has been widely discussed by sports writers, but this problem has largely ceased. See KenNeth L. Shropshire, In BLACK and White at xix (ig96). A similar open and notorious phenomenon exists with respect to access to head coaching positions in professional football, manager positions in professional baseball, or front office positions in either sport. See generally id.

123. When the white candidate is chosen, since "white" is the norm, at the conscious level no explicit racial information is involved.

I24 See generally Devah Pager, The Mark of a Criminal Record (Nov. 2002) (unpublished Ph.D. dissertation, Northwestern University) (on file with the Hastings Law Journal). Ms. Pager used matched pairs of "testers" to audit the extent to which a criminal record affected subsequent employment outcome. She found that a criminal record is associated with a fifty percent reduction in employment opportunities for whites and a sixty-four percent reduction for blacks. The more dramatic finding was that seventeen percent of whites with criminal records received call backs for interviews with employers, more favorable treatment than the African-American without criminal records, only fourteen percent of whom received call backs. See also Marianne Bertrand \& Sendhil Hullainathan, Are Emily and Greg More Employable than Lakisha and Jamal? A Field Experiment on Labor Market Discrimination (MIT Dep't. of Econ. Working Paper No. 03-22, 2003), available at http://ssrn.com/abstract=422902 (finding that fictitious resumes with African-American sounding names receive markedly fewer callbacks for job interviews than comparable fictitious resumes with White sounding names and that higher quality resumes for African-American names also elicit substantially fewer callbacks than comparable resumes for White names). 
information) operates much like nepotism, but to the opposite effect. Objective assessments about loved ones can be impossible for many people. Race may have an analogous effect because, like nepotism, it clouds judgment.

Another decisional effect of racial information results from the social demography of American society, notably its pervasive segregation. Employers and managers often use social and professional networks to confirm the reliability of information provided by job applicants and potential customers or suppliers. Paper credentials have limited value. The most valuable reference is one known to the decision maker, especially a reference with more substantial ties to the decision maker than to the candidate. In this latter case, the risk of reputational injury to the reference if it falsely confirms exaggerated and unwarranted claims by the candidate assures the decision maker of the accuracy of the reference. Unfortunately, given the high degree of segregation in our society, African-American and other minority candidates are less likely to have references also known to the decision maker. ${ }^{125}$ This phenomenon is less consequential for entry level jobs or small, episodic business transactions, but the more senior and powerful the job, or the larger and more significant the transaction, the more crucial it becomes that decisions be based upon reliable information. At the top of the employment and business transaction pyramids a considerable degree of common interconnected networks exist, and this interconnectivity increases the disadvantage of those who do not belong. Insiders who share more social and professional networks with the decision maker can have the substance of their nominal credentials and performance claims more easily confirmed than outsiders. If, to overcome this disadvantage, outsider candidates devote time and resources to establishing a reputation within the social and professional networks of the decisionmaker, they have increased their costs, simply changing the form of their disadvantage, but not eliminating it. $^{126}$

\section{CONCLUSION}

Volumes have been written about the many economic disparities between white and black Americans. ${ }^{127}$ For decades, scholars have debated the causes of the persistence of these inequalities. ${ }^{128}$ Some blame

125. This phenomenon of social segregation, especially with respect to housing and the neighborhood school (which reflect housing patterns), affects other minority groups to varying degrees. Hispanics are less segregated than African-Americans and Asian-Americans are even less segregated. See MASSEY \& DENTON, supra note 5.

126. This would be analogous to establishing a business overseas in a foreign society and learning the language, customs, and mores of that society in order to fit in.

I27. See, e.g., MYRDAL, supra note 77.

128. See, e.g., EConomics AND Discrimination, supra note 37 . 
the continuing legacies of slavery and Jim Crow; ${ }^{129}$ others blame continuing discrimination, while others seek answers in the structures of the economy that perpetuate racial inequalities as class distinctions. ${ }^{130}$ Few emphasize the obvious-the anemic state of black business activity. ${ }^{\mathrm{I} 1}$

In the dominant market economy on the planet in an era of global interdependence, it is inconceivable that racial inequalities will disappear so long as such wide divergences exist between the rates and scale of African-American business ownership and the national average. How much of this deficit is attributable to prior discrimination, and how much to continuing racial barriers is unclear, and additionally, these two categories are not analytically distinct. Discrimination in business to business transactions is not prohibited. As a practical matter, it cannot be. Given current trends in Supreme Court opinions, race conscious business development programs will soon be barred. ${ }^{132}$ In any event, existing equal protection doctrine has so distorted these programs that whatever marginal success they have had as business development tools is purely coincidental, leaving market-based race-neutral programs as the only remaining remedy to achieve economic equity.

Yet we lack the analytical tools and infrastructure to conduct the kinds and varieties of economic analysis needed to inform policy development. In the current intellectual climate the insights into racial phenomena that economics might make available would lack credibility within key African-American constituencies. The difficulty is thus twofold. First, the credibility of economics must be restored in the eyes of a constituency predisposed to view racial discrimination as a psychological, sociological, and cultural phenomena, but doubtful that economic analysis provides useful insights. Second, economic analysis must proceed in such a way that it generates market-based policies that plausibly promise to improve the situation.

Restoring credibility to economics, the first task and the start of which this essay aspires to attempt, requires showing how Law and Economics erred. More critical to this task than contesting its assumptions, which others have done both much earlier and far better than I, is to show how Law and Economics erred even by the lights of its own highly debatable assumptions. To this end this essay examined how Law and Economics scholars overlooked even the possibility that victims of discrimination could experience psychic costs. When psychic income

I29. Id.

I30. Id.

13I. See supra notes 84-106 and accompanying text.

132. See City of Richmond v. J. A. Croson Co., 488 U.S. 469 (1989); Adarand Constuctors, Inc. v. Pena, 515 U.S. 200 (I995). 
effects for African-Americans are modeled along with those for whites, the policy implications dramatically differ from those typically espoused by Law and Economics scholars. Market competition provides no assurance that nondiscriminatory firms will supplant discriminatory ones. Antidiscrimination laws no longer appear inefficient or wasteful. Law and Economics scholars, in extending an analysis developed to explain firm specific phenomena to a complex historical and cultural phenomenon like racial discrimination, ignored the limiting assumptions ${ }^{133}$ upon which neoclassical economics depends.

The second task involves conceptualizing race and racial barriers in ways that generate policy proposals whose implementation might erode the racial barriers constraining the opportunities available to minority business firms. Thinking about race as a special type of information, with a corrosive effect on both related information and on those who use it, contrasts markedly with the neoclassical approach. ${ }^{134}$ It avoids the diametric contradiction to the historical record that epitomized the Law and Economics preference model, and it rejects the rational choice theory at its core. ${ }^{135}$

Conceiving the problem as, in part, an information problem suggests some possible solutions. If information is part of the problem, either insufficient information or defective processing of available information, ${ }^{136}$ then policies that reward obtaining additional information or which create benefits for those that process information more accurately seem likely to erode the racial barriers that inhibit the formation and growth of African-American business firms. ${ }^{137}$ Describing racial phenomena in terms of information problems is also consistent with the historical record and has considerable explanatory power. Whether this approach or some other one ultimately proves more

133. The core assumptions have been articulated as "I) the assumption of rational, maximizing behavior by agents with given and stable preference functions; 2) a focus on attained, or movements toward, equilibrium states; and 3 ) the absence of chronic information problems (there is, at most, a focus on probabilistic risk: excluding severe ignorance, radical uncertainty, or divergent perceptions of a given reality)." Geoffrey M. Hodgson, The Return of Institutional Economics, in THE HANDBOOK OF Economic Sociology 6o-6r (Neil J. Smelser \& Richard Swedberg eds., I994). Another assumption critical to the analysis of this article is that market exchanges occur between equals. See MARK Seidenfeld, Microeconomic Predicates to Law and Economics 35 (1996).

134. Neoclassical microeconomics assumes perfect information or at least no information problems.

135. Rational choice theory is a useful analytical tool for certain purposes; it is not an accurate or comprehensive description of reality. The challenge to critics of rational choice theory is to develop a model with greater explanatory power and with fewer distortions or inadequacies.

136. An information approach allows incorporation of the irrational element of prejudice from the psychological model.

137. See generally Robert E. Suggs, Bringing Small Business Development to Urban Neighborhoods, 30 HARv. C.R.-C.L. L. REv. 487 (1995); Robert E. Suggs, Rethinking Minority Business Strategies, 25 HaRv. C.R-C.L L. REv. 101 (I990). 
beneficial, thinking about race in economic terms is essential to the creation of business development policies, and without exponential increases in the scale and sophistication of African-American business, substantive equality will remain elusive. 
*** 